\title{
Entropi Temelli MAUT ve SAW Yöntemleri İle Otomotiv Firmalarının Performans Değerlemesi Nuri ÖMÜRBEK ${ }^{1} \quad$ Meltem KARAATLI $^{2} \quad$ Halil Furkan BALCI $^{3}$ \\ $\ddot{O} z$
}

Bu çalışmada ülkemizde faaliyet gösteren ve aynı zamanda BISST'de (Borsa Ístanbul) işlem gören otomotiv sektöründe faaliyette bulunan firmaların performanslarının çok kriterli karar verme yöntemleri ile değerlendirilmesine çalışılmıştır. Türkiye'de faaliyet gösteren en önemli otomotiv şirketlerinin verileri; Sermaye, Hisse Senedi, Piyasa Değeri, Satış Geliri, Personel Sayısı, Net Kar Marjı, Cari Oran, net kar/sermaye, net kar/satışlar ve net satışlar/personel kriterleri çerçevesinde değerlendirilmiştir. Performans ölçümünde kullanılan kriterler ise firmaların 2014 faaliyet raporlarından elde edilmiştir. Öncelikle Entropi yöntemi ile kriterlerin ă̆ırlıkları belirlenmiştir. Elde edilen kriter ağırlıkları önce MAUT (Multi-Attribute Utility Theory) yönteminde daha sonra SAW (Simple Additive Weighting) yönteminde kullanılarak firmaların performansları değerlendirilerek sıralama yapılmıştır. Değerlendirme sonucunda her iki yöntemde de ilk üç sırada aynı firmalar yer almaktadir.

Anahtar Kelimeler: Çok Kriterli Karar Verme, Entropi, MAUT, SAW, Otomotiv

JEL Sinıflandirma Kodları: C44, M11

\section{Analyzing the Performances of Automotive Companies Using Entropy Based MAUT and SAW Methods}

\begin{abstract}
In this study, performances of automotive companies traded on BIST (Istanbul Stock Exchange) and also operated in our country have been compared with the multi-criteria decision making techniques. Data of the most important automotive companies operating in Turkey have been analyzed based on capital, stock certificate, marketing value, sales revenue, number of employees, net profit margin, current ratio, net profit/capital, net profit/sales and net sales/number of employees. Criteria applied on Performance measurement was gained operating reports of companies in 2014. Entropy method has been used to determine the weights of the criteria. Those weights have been used MAUT (Multi-Attribute Utility Theory) and SAW (Simple Additive Weighting) methods to rank automative companies' performances The findings highlight that the same companies were in the first three places in both methods.
\end{abstract}

Keywords: Multiple Criteria Decision Making, Entropy, MAUT, SAW, Automotive

JEL Classification Codes: C44, M11

\footnotetext{
${ }^{1}$ Doç. Dr., Süleyman Demirel Üniversitesi, İktisadi ve İdari Bilimler Fakültesi, İşletme Bölümü, nuriomurbek@sdu.edu.tr

${ }^{2}$ Yrd. Doç. Dr., Süleyman Demirel Üniversitesi, İktisadi ve İdari Bilimler Fakültesi, İşletme Bölümü, meltemkaraatli@sdu.edu.tr

${ }^{3}$ Yüksek Lisans, Süleyman Demirel Üniversitesi, Sosyal Bilimler Enstitüsü, İşletme Anabilim Dalı, furkanbalci48@gmail.com
} 


\section{N. ÖMÜRBEK - M. KARAATLI - H. F. BALCI}

\section{GíRiș}

İnsanlar hem özel hayatlarında hem de meslek hayatlarında olsun çoğu kez karar vermek durumunda kalmışlarıdır. Verilen bu kararlardan bazıları uygulanırken bazıları ise uygulama kısmında bırakılmıştır. Karar, bir fırsatı değerlendirmek veya sorunu ortadan kaldırmak için verilir. (Aktaş vd., 2015: 3) Karar verme kavramı bir kişinin, yöneticinin, kurumun veya karar verici bir bireyin genellikle birbirine alternatif olan seçenekler arasından birini seçme veya tercih etme eylemi olarak tanımlanabilir. Çok kriterli karar verme ise bir amaca ulaşmak için, var olan alternatifler kümesini belirlenmiş kriterler ile değerlendirerek optimum kararın alınmasına yardımcı olan yöntemler dizisidir. Birinci adımda elde edilen alternatif ve kriterlere göre verilen kararlar bir araya getirilir. İkinci adımda ise bu kararların derecelendirilmesi yapılarak en uygunu seçilmektedir (Aytaç ve Gürsakal, 2015: 2).

Otomotiv sektörü genel hatlarıyla, karayolunda kullanılan araçları ve bu araçların üretiminde kullanılan parça ve yedek parçaları üreten bir sanayi kolu şeklinde tanımlanmaktadır. Türkiye'de otomotiv sektörü; meydana getirdiği katma değer, istihdama faydası, vergi gelirleri ve birçok sanayi kolundaki talep yaratıcı konumu ile ekonomik açıdan önemli bir role sahiptir. Ayrıca sektör, yeni teknolojilerin ülkemize aktarılmasında da önemli rol oynamaktadır (Görener ve Görener, 2008: 1213).

Türkiye'de otomotiv sektörü üretime 1950'lerin ortalarında başlamış ve üretim 1960'ların ortalarından itibaren hızlanmıştır. 1950'li yıllarda bazı örnek araçların üretilmesinden sonra ilk gerçek montaj hattı 1954'te silahlı kuvvetlere jip ve kamyonet üretimi için kurulmuş, 1955 'te kamyon ve 1963 'te otobüs montajına başlanmış, takip eden üç yıl içinde de binek otomobil üreten montaj fabrikaları (Tofaş-Fiat, Oyak-Renault, Otosan-Ford) imalata geçmiştir. 1966'da ise otomotiv sanayi kendi modellerinin montajına başlamış ve Otosan tarafından o dönemlerin otomobili Anadol üretilmiştir. İki büyük otomobil üreticisi Tofaş ve Oyak-Renault, İtalyan ve Fransız lisanslarıyla 1971'de imalat hatlarını kurmuşlardır (Görener ve Görener, 2008: 1218). 
Otomotiv sektöründe performans değerlendirmesinin yapılması, işletmenin mevcut performansı hakkında bilgiye ulaşmasını sağlarken aynı zamanda sektördeki yerini görme açısından da önem taşımaktadır. Diğer yandan işletme içinde daha fazla önem verilmesi gereken bölümlerin tespiti, rakip firmalara göre artı ve eksilerin bilinmesi konusunda da performans değerlendirmesinin yapılması önemlidir.

Bu çalışmada ülkemizde 2014 yılında faaliyet göstermiş ve borsada işlem gören en önemli otomotiv firmalarının performanslarının değerlendirilmesine çalışılmıştır. Çalışmada öncelikle literatür özetleri verilecektir. Daha sonra Entropi, MAUT (Multi-Attribute Utility Theory) ve SAW (Simple Additive Weighting) yöntemleri hakkında açıklamalar yapılacak ve son olarak da firmaların performanslarının değerlendirilmesinde kullanılan uygulama bölümü yer alacaktır.

\section{LITERATÜR İNCELEMESI}

-Otomotiv Sektöründe Performans Ölçümü İle İlgili Yapılan Bazı Çalışmalar

Yaylalı ve Çalmaşur çalışmalarında farklılaştırılmış oligopol piyasası örneği olan Türk otomotiv sektörünün 1992-2011 dönemleri arasındaki üretim maliyetini ve toplam faktör verimliliği üzerine bir çalışma yapmışlarıdır. Teknik olarak veri zarflama analizi yöntemini kullanmıştır. Türk otomotiv sektöründe faaliyet gösteren bazı firmaların toplam faktör verimliliğindeki değişme ve bileşenleri yıl bazında incelenmiştir (Yaylalı ve Çalmaşur, 2014: 325-350).

Ballı vd., çalışmalarında en uygun otomobili seçmek için AHP ve bulanık TOPSIS yöntemlerini kullanmışlardır. Alternatifler olarak kullanılan aynı sınıftan yedi farklı otomobili fiyat, yakıt, performans ve güvenlik kriterleri kullanarak değerlendirmişlerdir. Elde edilen sonuçların tutarlı ve uygun olduğu görülmüştür (Ball1 vd., 2007: 139-147).

Yıldız, çalışmasında Türk sanayisinin en önemli kollarından olan otomotiv sektörünün etkinlik ve etkililiğini hesaplayarak sektöre ilişkin performans sonuçlarını elde etmeye çalışmıştır. Değerlendirmede Veri Zarflama Analizini kullanmıştır. Elde edilen sonuçlara göre hiçbir firmanın hem etkinliği hem de 


\section{N. ÖMÜRBEK - M. KARAATLI - H. F. BALCI}

etkililiği bir arada sağlayamadığı görülmüştür. Diğer bir deyişle, hiçbir otomotiv firması etkinlik-etkililik matrisinin yıldız bölgesinde yer alamamıştır. Mevcut performans gelişimine yönelik elde edilen etkinlik sonuçları, firmaların girdi değerlerini 0,90 oranında azaltmaları gerektiğini ortaya koyarken, etkililik değerleri de firmaların faaliyet karlarını büyük ölçüde artırmaları gerektiğini göstermiştir (Yildız, 2006: 1-12).

Yurdakul ve İç, çalışmalarında Türkiye'de otomotiv sanayiinde faaliyet gösteren ve İMKB'de (İstanbul Menkul Kıymetler Borsası) işlem görmekte olan beş büyük ölçekli otomotiv firmasının 1998-2001 yılları arasındaki bilançolarını kullanarak firmaların sıralandırılmasına yönelik bir örnek çalışma yapmışlardır. Çok Nitelikli Karar Verme Yöntemleri'nden TOPSIS (Technique for Order of Preference by Similarity to Ideal Solution) yöntemi kullanılarak sonuçlar genel firma performanslarını gösteren tek bir puana çevrilmiştir. İşlem gören hisse senetlerinin değerleri her yıl için tespit edilmiş ve TOPSIS ile bulunan sonuçlarla karşılaştııılmıştır. Karşıllaştırma sonucunda TOPSIS yöntemi sonuçları ile İMKB hisse senedi değerlerinin sıralaması birbiriyle tutarlı çıkmıştır (Yurdakul ve İç, 2003: 1-18).

Gümrük birliği sürecinde otomotiv yan sanayinde faaliyet gösteren KOBİ’ lerin rekabet yapılarını ayrıntılı bir şekilde analiz etmek ve etkin rekabet strateji yöntemlerini geliştirmek için SWOT analizine uygun bir anket çalışması otomotiv yan sanayinde faaliyet gösteren 34 orta ölçekli işletme üzerinde yapılmıştır. Çalışma sonunda KOBİ' lerin gelişmesiyle birlikte Türk ekonomisi daha dinamik ve rekabetçi bir yapıya kavuşacağı anlaşılmıştır (Çetin, 2000: 69-84).

-Entropi Yöntem İle İlgili Yapılan Bazı Çalışmalar

Çin'de 2011 yılından bu yana yoksullukla mücadele için yeni stratejiler uygulanmaya başlanılmıştır. Yoksul olan on dört bölge değerlendirmeye alınmıştır. Bunun için kapsamlı değerlendirme değeri, ekonomik kalkınma, sosyal kalkınma, üretim ve yaşam, yoksullukla mücadelede ilerleme gibi kriterler Entropi yöntemi 
ile değerlendirilerek, yoksullukla mücadelenin etkilerinin ölçümü yapılmıştır (Chen vd., 2015: 89-98).

Yeraltı sularının sürdürülebilirliğinin değerlendirilmesi ve geliştirilmesi için AHP (Analytic Hierarchy Process) ve Entropi yöntemleri kullanılmıştır. Sosyoekonomik talep, ekoloji ve çevre, yeraltı kaynakları gibi kriterlerin ağırlıkları hesaplanarak daha doğru sonuçlar elde edilmiştir. Yeraltı sularının imar ile ilgili durumlarının değerlendirilmesine de yardımcı olmuştur (Zhang vd., 2015: 23532363).

Kore ve Tayvan'daki nakliye şirketlerinin mali konumlarını karşılaştırmak için Entropi ve Gri İlişkisel Analiz yöntemi kullanılmıştır. Her iki ülkenin başlıca konteyner nakliye şirketleri Evergreen, Yang Ming, Hyundai ve Hanjin değerlendirmeye alınmıştır. Birinci adımda 4 şirketin her yıl için finansal oranlarının nispi ağırlıkları Entropi yöntemi ile hesaplanmıştır. İkinci adımda ise gri ilişkisel analiz yöntemi ile şirketler sıralanmıştır. Bu çalışma sayesinde dünya denizcilik alanında finansal tsunami etkilerini hafifletmek için bir iş politikası önerilmeye çalışılmıştır ( Lee vd., 2012: 5649-5657).

Gıda-atık güvenliğinin değerlendirilmesinde Entropi ve Analitik Hiyerarşi Süreci temelli olarak kriter ağırlıkları değerlendirilmiştir. Entropi ve AHP yöntemleri kullanılarak ürün güvenliği kapsamlı bir şekilde değerlendirilerek gıdaatık beslemesi test verilerine dayanan bir yöntem oluşturulmaktır. Ürün güvenliği analizi ve üretim için gıda atıklarından üretilen hayvan yeminin kontrolü oldukça önemlidir (Chen vd., 2014: 7328-7337).

Çok kriterli karar verme yöntemleri ile tedarikçi seçimi için kriter ağırlıklarının belirlenmesinde Entropi yöntemi kullanılmıştır. Çalışmada; ürün kalitesi, işbirliği kurma çabası, tedarikçilerin teknik düzeyi, teslimat süresi, fiyat ve maliyet gibi kriterler dikkate alınmıştır (Shemshadi vd., 2011: 12160-12167).

Gözlem ağ1 sayesinde elde edilen bilgiyi sayısal olarak tanımlayabilen Entropi yöntemi, su kalitesi gözlem ağlarının tasarımında önemli bir role sahiptir. Entropi yönteminin gözlem ağı tasarımında kullanılabilirliği konusundaki araştırmalar; 


\section{N. ÖMÜRBEK - M. KARAATLI - H. F. BALCI}

istasyon seçimi, gözlem sıklığı, konum/zamana göre tasarım, değişken seçimi ve ölçüm süresi gibi teknik tasarım kriterlerinin elde edilmesini sağlamıştır. Yapılan çalışmada gözlem ağlarının zaman/konum bileşenlerine göre Entropi yöntemiyle değerlendirilmesinde yeni bir yöntem ortaya koyulmaktadır. Sonuçlar Gediz Nehri boyunca gözlenmiş su kalitesi verileri kullanılarak elde edilmiştir (Özkul, 2001: 435-452).

Çok Nitelikli Karar Verme ve Bankaların Mali Performanslarının Değerlendirilmesi Örneği adlı yüksek lisans tezinde nesnel ağılıkların belirlenmesi için Entropi yöntemi kullanılmıştır (Çınar, 2004: 103).

Bostancı vd., kentsel silüetin çeşitlilik açısından değerlendirilmesinde Entropi yöntemini kullanmışlardır. Çalışmada farklı ülkelerden kent silüetlerinin estetik açıdan çeşitli özelliğinin Entropi yöntemi ile değerlendirilmesi anlatılmıştır. Böylece Entropi analizinin kentsel estetik değerlendirmeye katkıları ortaya konulmuştur (Bostanc1 vd., 2006: 83-95).

\section{-MAUT Yöntem İle İlgili Yapılan Bazı Çalışmalar}

Petrol ve gaz endüstrisi gibi riskli faaliyetlerde bulunan işletmeler risk ve belirsizlik durumlarında karar verme ile karşı karşıyalardır. Lopes ve Almeida çalışmalarında arama ve üretim projelerinin değerlendirilmesini amaçlamışlarıdır. Petrol ve gaz alanlarının üretimini geliştirmeyi amaçlayan bir proje seçiminde projenin sinerjisi, doğa ve karar vericinin tercih yapısını dikkate alarak petrol ve gaz endüstrisine dayalı bir portföy projesi seçiminde, MAUT yöntemini kullanmışlarıdır (Lopes ve Almeida, 2015: 131-140).

Yazılımların en önemli uygulamalarından biri yazılımların güvenlik analizi sürümünün belirlenmesidir. Analiz için yeni bir model geliştirilmiştir. Yükseltilmiş yazılım ve optimal yükseltilmiş yazılımın maksimum arıza giderme süresi serbest zaman da test edilmiştir. Yazılım yöneticileri testi durdurmak ya da yazılımı serbest bırakmak konusunda kararsız kalmaktadırlar. Bunun için birden fazla sürümü olan yazılımlarda güvenilirlik, maliyet, teslim süresi ve arıza yoğunluğu 
fonksiyonu gibi kriterleri ele alarak MAUT yöntemini kullanmışlarıdır (Kapur vd, 2015: 61-70).

Alp, Öztel ve Köse, çalışmalarında kurumsal sürdürülebilirlik performansının ölçümü için uluslararası alanda kimya sektöründe faaliyet gösteren Linde adında bir firmanın 5 yıllık faaliyetlerini incelemişlerdir. Entropi yöntemi ile ağırlıkları elde ettikten sonra MAUT yöntemini kullanarak performans ölçümünü yapmışlardır. Ekonomik ve sosyal sürdürülebilirlik performansları artan bir eğilim gösterirken çevresel sürdürülebilirlik performans1, istikrarsız bir görünüme sahiptir (Alp vd., 2015: 65-81).

Bir üretim tesisinde en etkili malzeme taşıma ekipmanını seçmek için MAUT ve Monte Carlo simülasyonu kullanılmıştır. Malzeme taşıma seçim süreci çok kriterli karar verme problemi olarak sınıflandırılabilir. Bu seçim, dört alternatif ve kontrol, güvenlik, bakım, değişkenlik gibi kriterler kullanılarak yapılmıştır (Ahmed ve Lam, 2014).

Kim ve Song, çalışmalarında optimum bir demontaj (söküm) projesinin seçilmesini amaçlamışlardır. Projenin seçilmesinde; demontaj programı, demontajın maliyeti, işçi pozlama ve işgücü maliyeti kriterler olarak seçilmiştir. AHP ve MAUT yönteminden elde edilen sonuçlara göre AHP yönteminin bir söküm projesi için daha uygun olduğu sonucuna varılmıştır (Kim ve Song, 2009:145-150).

Acil servislerin kalabalık olması dünya çapında birçok ülkede sorun olduğu gibi $\mathrm{ABD}$ de büyük bir sorundur. $\mathrm{Bu}$ sorun hastaların güvenliğini büyük ölçüde etkilemektedir. Bulanık AHP ve MAUT yöntemine göre hastaları karakteristik özelliklerine göre sıralamak için asıl şikayeti, yaşı, cinsiyeti, ağrı düzeyi ve vital bulguları değerleri kriterler olarak kullanılmıştır. Elde edilen sonuçlara göre hasta sayısını en aza indirmek ve klinik ortamlarda karar verme hatalarını azaltmak için Bulanık AHP ve MAUT yöntemi kullanılabileceği sonucuna varılmıştır (Ashour ve Okudan, 2013: 177-187). 


\section{N. ÖMÜRBEK - M. KARAATLI - H. F. BALCI}

Gelişmekte olan ülkelerde ve homojen olmayan sosyo-ekonomik toplumlarda sağlık sistemlerinin seçimi oldukça karmaşıktır. Alternatiflerin uygunluğunu değerlendirirken destek planlamacıları SANEX adında bir karar destek sistemi geliştirmişlerdir. SANEX iki adımda alternatifleri değerlendirmektedir. İlk olarak teknik ölçütlere göre 20 kriter uygun alternatifleri değerlendirmek için kullanılmıştır. Daha sonra MAUT tekniği kullanılarak, sosyo-kültürel ve kurumsal kriterlerin uygulanabilirliği ve sürdürülebilirliği açısından alternatiflerin karşılaştırılması sağlanmıştır (Loetscher ve Keller, 2002: 267-290).

Singapur da yedi parametreye göre tapınak inşaatı için uygun yer seçiminde MAUT yöntemi kullanılmıştır. Tapınak inşaatında; toprak tipi, kazı büyüklüğü, kazı derinliği, önerilen yöntemler, yakınlık, taban suyu ve zemin geçirgenliği kriterleri MAUT yöntemi ile değerlendirilmiştir (Wang vd., 2002: 625-645).

Gomez-Limon vd., riskten kaçınmaya yönelik faktörleri, çok kriterli karar verme yöntemi olan MAUT yöntemi ile değerlendirmişlerdir. Riskten kaçınma katsayısının değerlendirilmesi, sonuçların karşılaştırılması, riskin nasıl değiştiğinin ortaya çıkarılması ve tarımda üretimi en çok etkileyen risk faktörünü bulmak için MAUT yöntemini kullanmışlardır. Çiftlik boyutu, toprak mülkiyeti yüzdesi, yaş, aile boyutu, tarımdan elde edilen gelirin yüzdesi ve eğitim değerlendirme kriterleri olarak belirlenmişlerdir (Gomez Limon vd., 2003: 570-585).

Ananda ve Herath, Avustralya'da orman arazi kullanımı açısından risk tercihlerinin uygulamasında ve doğal kaynak yönetimindeki sorunlar nedeniyle MAUT yöntemini uygulamışlardır. Ananda ve Herarth'ın yaklaşımın da toplumsal risk tercihleri etrafında yoğunlaşan ve arzu edilen nitelikler incelenerek, incelenen sonuçların değerlendirildiği bir anket kullanmışlardır. Veriler ise eski ormanları koruma, kereste üretimi ve orman rekreasyonudur. Genel olarak, muhafazakar orman arazi kullanım seçeneği tercihindeki risk tutumlarını ele almışlardır (Ananda ve Herath, 2005: 408-419).

Şirketlerin küresel üretim tesisi kurmak için Meksika, Çek Cumhuriyeti, Polonya, Güney Kore ve Güney Afrika ülkeleri MAUT yöntemi ile 
değerlendirilmiştir. Ülke seçiminde altyapı, kalite, GSYİH (Gayri Safi Yurt İçi Hasıla), enflasyon oranı ve işgücü maliyeti kriterleri MAUT yöntemi ile değerlendirilmiştir (Canbolat vd., 2007: 312-325).

Acil durum yöneticileri kritik tahliye kararı verebilmek için MAUT yöntemini kullanmışlardır. Devlet daireleri tarafından geliştirilen ERGO, tahliyeler için uygun bir model geliştirilmek üzere ortaya konulmuştur. Bu model MAUT yöntemiyle firtına dalgalanmalarını değerlendirmek ve acil durum yöneticileri tarafından tahliye eylemlerinin değerlendirilmesinde kullanılmıştır. Veriler, Avrupa'nın sekiz farklı ülkesinde acil durum yöneticileri tarafından toplanmış ve herhangi bir eylemin olmaması, tehlike anında danışma, hafif tahliye emri ve acil tahliye emri kriterleri dikkate alınmıştır. Ortaya konulan model tahliye politikaları analizleri ve olası senaryoların değerlendirilmesinde kullanılmıştır. Sonuç olarak tahliye politika analizi ve eğitim senaryoları oluşturulması kararına varılmıştır (Kailiponi, 2010: 163-174).

Türkoğlu ve Uygun, Çukurova bölgesel havaalanı yeri seçimi için MAUT ve VIKOR (Vise Kriterijumska Optimizacija I Kompromisno Resenje) yöntemlerini kullanmışlardır. Kriterler olarak; maliyet, tarım arazi kullanımı, narenciye bahçesi potansiyeli, arazi kodu, nüfus, kapsadığı hizmet alanı, zeminin jeolojik özellikleri, dolgu ihtiyacı, biyolojik çeşitlilik, fay hattı potansiyeli, çevrenin gelişimi, topoğrafya, kara ulaşımına erişim ve atmosfer koşulları olarak belirlenmiştir. VIKOR yönteminde en iyi iki alternatif olarak, Mersin-Kargılı ve Mersin-Çeşmeli alternatifleri seçilmiştir. MAUT yönteminde ise en iyi iki alternatif olarak MersinKargılı ve Mersin-Çiçekli alternatifleri seçilmiştir. Sonuçta iki yöntemde de en iyi seçim Mersin-Kargılı alternatifi çıkmıştır (Türkoğlu ve Uygun, 2014: 1425-1433).

MAUT yöntemi ile günümüz akıllı telefonları arasından en çok fayda sağlayan telefonun seçilmesi hedeflenmiştir. Ağırlıkların tespiti için Entropi yöntemi kullanılmıştır. Bu yöntemin kullanımı ile ağılıkların belirlenmesinde daha nesnel sonuçlar elde edilmiştir. MAUT yöntemi ile güncel olarak kullanılan 10 adet akı1lı telefon arasından en çok fayda sağlayan telefonun seçimi yapılmıştır. MAUT yönteminin uygulanması sonucu toplam fayda değeri en büyük olan akıllı telefon 


\section{N. ÖMÜRBEK - M. KARAATLI - H. F. BALCI}

Nokia Lumia 1020 modeli olarak tespit edilmiştir (Konuşkan ve Uygun, 2014: 1404-1412).

\section{-SAW Yöntem Ille İlgili Yapılan Bazı Çalışmalar}

Sağlik sisteminin en önemli bileşenlerinden birisi ilaç tedarikidir. Özellikle ülkelerde başlıca ilaçların tedariki yerel ilaç firmaları tarafından sağlanmaktadır. İlaç şirketlerini etkileyen herhangi bir risk ya da arz gibi etkenler ilaçlar ve sağlık sisteminin etkinliğini bozabilir. İran'daki ilaç sektöründe risk değerlendirmesi, tehlike ve risklerin olasılığının incelenmesi için beş fonksiyon (tedarik yönetimi, finans yönetimi, operasyon yönetimi, kalite yönetimi ve satış yönetimi) ele alınarak SAW yöntemi ile değerlendirilmiştir (Jaberidoost vd., 2015: 1-10).

Günümüzde belediyeler katı atık deponite alanı için uygun yer bulamamaktadırlar. Çünkü uygun depolama alanı konusunda birçok çevresel, ekonomik, teknik ve sosyo-kültürel zorluklar ortaya çıkmaktadır. Dört alternatif ve sekiz kriter kullanılarak SAW yöntemi ile uygun sıralama yapılarak alternatifler değerlendirilmiştir (Eskandari vd., 2015: 7754-7765).

Heterojen kablosuz ağlarda kablosuz ağ kullanıcıları için şebeke seçimi önemli bir role sahiptir. Heterojen kablosuz ağlarda ağ seçimini gerçekleştirmek için SAW yöntemi kullanılmıştır. Ağ seçimi için üç kullanıcı Wi-Fi, Wi-max, UMTS gibi kriterler bazında değerlendirilmiştir. Sonuçlara göre en iyi ağ, kullanıcı tercihlerine göre belirlenmektedir (Salih vd., 2015: 1112-1125).

Wu vd., bankacılık performansının ölçülmesinde SAW, TOPSIS ve VIKOR yöntemlerini kullanmışlardır. Bankacılık sektörüne ilişkin literatür taraması ve uzman görüşlerini kullanılarak 23 kriter çerçevesinde banka performanslarının ölçümü yapılmıştır (Wu vd., 2009: 10135-10147).

Bir güç kaynağının seçiminin değerlendirilmesi için SAW ve Veri Zarflama Analizi yöntemleri kullanılmıştır. Sabit ve değişken harcamalar, enerji santrali kapasiteleri, yaşam döngüsü ve geri ödeme süresi gibi kriterler kullanılarak değerlendirme yapılmıştır. IGCC' nin değerlendirme sonuçlarına göre SAW yöntemi onaylanmıştır (Shakouri vd., 2014: 640-647). 
Beş farklı uzmandan görüşler alınarak, dört adet robot; hız, yükleme kapasitesi, maliyet ve tekrarlanabilirlik kriterleri açısından SAW yöntemi ile sıralanmıştır ve en iyisi olarak bir numaralı robot seçilmiştir (Goh vd., 1995: 193-196).

Küçükönder ve Karabulut, SAW yöntemini kullanarak Kahramanmaraş’ta çöp depolama alanı tespit etmeyi amaçlamışlardır. Seçilen dört bölgede kullanılan kriterler topografya, toprak, jeoloji, hidroloji, ana ulaşım hatları, yerleşim alanları ve güncel arazi kullanımıla ilgili bilgilerdir. Bir numaralı alternatif alanın topografik, jeolojik ve ulaşım özellikleri açısından uygun bir depolama alanı özelliği taşıdığı sonucuna varmışlardır (Küçükönder ve Karabulut, 2007: 55-76).

Dördüncü nesil kablosuz ağları elde etmek için kesintisiz bağlantı "DEVİR" tekniği kullanılmıştır. Heterojen Kablosuz ağlarda temel zorluk Wi-Fi, Wi-Max, W-LAN, W-PAN vb gibi farklı ağlar arasında bağlantı seçilmesidir. SAW yöntemi ile mobil terminal tarafından sürekli bağlantı için ziyaretçi ağların hangi ağ 1 seçmesi gerektiği belirlenmiştir. Çalışmanın sonucunda Wi-Max cell A2 ile bağlanmasının iyi olacağı tespit edilmiştir (Savitha ve Chandrasekar, 2011: 18-24).

İmalat sanayi kalitesini ölçmek için SAW yönteminin uygulandığı bir çalışmada, imalat sanayi kalitesini etkileyen kritik başarı faktörleri literatür taraması yapılarak ortaya konulmuştur. Bu faktörler; insan kaynakları, malzeme, planlama, örgüt kültürü, makine ve metodolojidir. Yöntemin uygulanması sonucu en iyi endüstri dalı, A endüstrisi seçilmiştir (Antil ve Singh, 2013: 1-13).

Lojistik firmalarında performans ölçümü için SAW yöntemi tercih edilmiştir. Normalizasyon işleminde net satışlar ve EFKM fayda kriteri olarak, diğer dört kriter ise maliyet kriteri olarak değerlendirilmiştir. Daha sonra da alternatiflerin performans değerleri hesaplanmıştır (Çakır ve Perçin, 2013: 449-459).

Abdullah ve Adawiyah, uzmanların görüşünü kullanarak personel seçimi gerçekleştirmişlerdir. Bu modelde kullanılan veriler, beş uzmandan toplanmıştır. Anket verilerini toplamak için 1'den 5'e kadar ölçek değerleri kullanılarak, İran telekomünikasyon şirketlerinden biri kullanılmıştır. Beş personel arasından en iyisini seçmek için nitel ve pozitif yedi kriter kullanılmıştır. Kriterler; farklı iş 


\section{N. ÖMÜRBEK - M. KARAATLI - H. F. BALCI}

birimleri, geçmiş deneyimler, takım oyuncusu, bir yabancı dilde akıcılık, stratejik düşünme, sözlü iletişim becerileri ve bilgisayar becerileridir. SAW yöntemi sonucunda P3 elemanının seçilebilir en iyi eleman olduğu görülmüştür (Abdullah ve Adawiyah, 2014: 34-49).

\section{METODOLOJI}

$\mathrm{Bu}$ çalışmada çok kriterli karar verme yöntemlerinden Entropi, MAUT ve SAW yöntemleri kullanılmıştır. Öncelikle kriter ağırlıklarının hesaplanması için Entropi yöntemi, daha sonra performans değerlemesi için de MAUT ve SAW yöntemleri kullanılmıştır.

\subsection{Entropi Yöntemi}

Nesnel ağırlıkları hesaplamak için karar matrisinin verileri bilindiği durumda Entropi yöntemi uygulanabilmektedir. Fizik ve enformasyon bilimlerinden alınan Entropi kavramı üzerine kurulan yöntemde karar matrisinin, nitelik önemine dair bilgiyi bünyesinde barındırdığı düşünülmektedir. Entropi yönteminin temel fikri bu bilginin veri kümeleri arasındaki karşıtlıklardan geldiğidir. Buna göre, niteliklerin nesnel ağırlıkları, alternatiflerin her niteliğe göre çıktılarının ne kadar ayrı veya farklılaşmış olduğu yani "karşıtllı̆̆ının yoğunluğu" tarafindan belirlenir. Bu karşıtlık ne kadar fazla ise ilgili nitelik tarafindan kapsanan ve iletilen bilgi de o kadar fazla olur (Çınar, 2004: 103). Entropi yönteminin adımları aşağıda görüldüğü gibidir (Wang ve Lee, 2009: 8982).

Adım 1: Karar matrisinin normalizasyonu eşitlik (1) yardımı ile hesaplanır.

$$
p_{i j}=\frac{X_{i j}}{\sum_{i=1}^{m} X_{i j}}
$$

i : alternatifler

$\mathrm{j}:$ kriterler

$\mathrm{p}_{\mathrm{ij}}$ : normalize edilmiş değerler

$\mathrm{x}_{\mathrm{ij}}$ : verilen fayda değerleri

Adım 2: Her bir kriter için Entropi değeri eşitlik (2) ile hesaplanır. 
$e_{j}=-k \sum_{j=1}^{n} p_{i j} \ln p_{i j}$

$\mathrm{k}:(\ln (\mathrm{n}))^{-1}$

$\mathrm{k}$ : entropi katsayıs 1

$e_{j}:$ entropi değeri

$\mathrm{p}_{\mathrm{ij}}$ : normalize edilmiş değerler

Adım 3: Her bir kriterin ağırlık değerinin hesaplanması eşitlik [3]' deki gibidir.

$$
\begin{aligned}
& \sum_{1}^{m} w_{j}=1 \\
& w_{j}=\frac{1-e_{j}}{\sum_{1}^{m}\left(1-e_{j}\right)} \\
& \mathrm{w}_{\mathrm{j}}: \text { ağırlık değerleri } \\
& \mathrm{e}_{\mathrm{j}}: \text { entropi değerleri }
\end{aligned}
$$

\subsection{MAUT Yöntemi}

Çok Kriterli Karar Verme (ÇKKV) (Multiple Criteria Decision Making MCDM); birden çok ve birbiriyle çelişen kriterlerin, gerçekleştirilmek istenildiği problemlerin çözümüne verilen genel bir ifadedir. (Zionts, 1979: 94) Çok kriterli karar verme yöntemlerinden biri olan fayda teorisi (MAUT), Fisburn (1967) ve Keeney (1974) tarafindan uygulanmaya başlanmıştır. Keeney'den sonra Loken 2007 yılında bu yöntemi geliştirmiştir. Son yıllarda gelişen dünyada gerçek bir analiz yapmak için MAUT yöntemini kullanmak olağan hale gelmiştir (Konuşkan ve Uygun, 2014: 1404).

Çok nitelik fayda teorisi (MAUT) sezgisel formüle etme ve karar verme problemleri için çok yararlı bir yöntemdir. MAUT yöntemi çelişen hedefler arasından seçim yapılabilmesi için mantıklı ve çözülebilir bir yol sağlamaktadır. MAUT yöntemi, değişkenleri karara vardırmak ve ortak bir temel sağlamak için sistematik şekilde çalışmaktadır (Kim ve Song, 2009: 145). Teorik ve pratik olarak 


\section{N. ÖMÜRBEK - M. KARAATLI - H. F. BALCI}

MAUT yönteminin uygulama prosedürleri vardır. Bu prosedürler beş aşamadan oluşur (Kim vd., 2007: 2);

- Hedefi ayarlama ve amaç için özelliklerin kurulması,

- Niteliklerin nicel rakamlarla oluşturulması,

- Bireysel niteliğin yarar fonksiyonlarının türetilmesi,

- Bireysel niteliğin ağırlık faktörlerinin hesaplanması,

- Çok kriterli fayda fonksiyonu türetilmesi.

MAUT yöntemi yaygın olarak Anglo-Saxon ülkelerinde kullanılmaktadır. Temel hipotez, her karar verici bilinçli ya da dolaylı yoldan tüm bakış açılarını bir araya getirerek optimize etmeye çalışır. Karar vericinin tercihleri, temsil edilen fayda fonksiyonu anlamına gelmektedir. Karar vericinin bu fonksiyonu karar verme sürecinin başında bilmesine gerek yoktur bu yüzden öncelikle fonksiyonu inşa etmek zorundadır. Fayda fonksiyonu, tercih edilebilirlik veya alternatifleri ölçmenin bir yoludur. $\mathrm{Bu}$ fonksiyon tüketim malları ya da hizmetler olabilir. Fonksiyon sayesinde karar vericinin refah düzeyini öğrenmek mümkündür.

Fayda fonksiyonu, bir alternatifi değerlendirme sağlayacak çeşitli kriterler oluşturmaktadır. Örneğin, bir akıllı telefon satın alınması durumunda en uygun akıllı telefonu seçmek için, kullanılabilir olanların küresel yararının ölçülmesi gerekmektedir. Bunun için genellikle fiyat, müşteri yorumları, boyut, kamera, batarya gibi çeşitli kriterler üzerine toplanan bir değerlendirme yapmak gerekmektedir. Her kriter için karar verici marjinal fayda puanı denilen, bir puan verecektir. Kriterlerin marjinal fayda puanları ise küresel yarar puanının ikinci aşamasında elde edilmiş olur (Ishizaka ve Nemery, 2012: 81-82). MAUT yönteminin adımları aşağıdaki gibidir (Ishizaka ve Nemery, 2012: 83).

Adım 1: Karar problemine konu olan kriterler $\left(\mathrm{a}_{\mathrm{n}}\right)$ ve kriterlerin seçilmesinde yardımcı olacak nitelikler/kriterler $\left(\mathrm{x}_{\mathrm{m}}\right)$ belirlenmelidir.

Adım 2: Niteliklerin doğru şekilde değerlendirilmesini sağlayan ve önceliklerin belirlendiği ağırlık değerlerinin $\left(\mathrm{w}_{\mathrm{j}}\right)$ ataması yapılır. Tüm $\mathrm{w}_{\mathrm{j}}$ değerlerinin toplamı eşitlik (4)' deki gibi 1'e eşit olmalıdır. 


$$
\sum_{j=1}^{q} w_{j}=1
$$

Adım 3: Kriterlerin değer ölçülerinin ataması yapılır. Bu atama nicel kriterler için nicel değerleri olurken nitel kriterler için ikili karşılaştırmalar göz önünde bulundurularak yapılır. Tüm bunların ışığında 5'lik 100'lük vb. sistemde değer atamalar1 yapilır $\left(\mathrm{x}_{\mathrm{m}}\right)$.

Adım 4: Atanan değerler karar matrisine yerleştirilerek normalize etme işlemine geçilir. Normalizasyon işleminde öncelikle her nitelik için en iyi en kötü değerler belirlenerek en iyi değere 1 , en kötü değere 0 değeri atanır ve diğer değerlerin hesaplanması için aşağıdaki eşitlik (5)'deki formül kullanılır.

$$
f j(a i)=\frac{f i(a i)-\min (f i)}{\max (f i)-\min (f i)}
$$

Adım 5: Normalizasyon işleminin ardından fayda değerlerinin belirlenmesi işlemine geçilir. Fayda fonksiyonu formülü eşitlik (6)'daki gibidir.

$$
U\left(a_{i}\right)=\sum_{j=1}^{q} f_{j}\left(a_{i}\right) \cdot w_{j}
$$

$U\left(a_{i}\right):$ Alternatifin fayda değeri

$f_{j}\left(a_{i}\right)$ : Her kriter ve her alternatif için normalize fayda değerleri

$w_{j}:$ Ağırlık değerleri

\subsection{SAW Yöntemi}

Churchman ve Ackoff (1954) tarafindan portföy seçim problemine uygulanılarak literatüre kazandırılan SAW (Simple Additive Weighting) yöntemi, literatürde Ağırlıklı Toplam Model (Weighted Sum Model) olarak da bilinmektedir (Çakır ve Perçin, 2013: 452). SAW yönteminde fayda kriteri için; her bir alternatifin her bir kriter açısından aldığı değerin max değere bölümünün kriter ağırlığı ile çarpılarak alternatif tercih değeri bulunur. Maliyet kriteri için ise her bir alternatifin her bir kriter açısından aldığı değerler içinden min. in her bir değere bölümünün kriter ağırlığı ile çarpılarak alternatif tercih değeri bulunur (Afshari vd., 2010: 511). 


\section{N. ÖMÜRBEK - M. KARAATLI - H. F. BALCI}

Matematiksel basitliği nedeniyle ÇKKV literatüründe en fazla kullanılan tekniklerden biri olan SAW Yönteminin adımları aşağıdaki gibidir (Yeh, 2003: 291).

Adım 1: Karar Matrisinin Normalize Edilmesi eşitlik (7)'deki gibidir.

$$
r_{\mathrm{ij}}=\left\{\begin{array}{lll}
\frac{X_{i j}}{\max X_{i j}} & i=1, \ldots ., m ; j=1, \ldots . n \text { fayda kriteri için } \\
\frac{\min X_{i j}}{X_{i j}} & i=1, \ldots ., m ; j=1, \ldots . n \text { maliyet kriteri için }
\end{array}\right\}
$$

SAW Yönteminde ilk aşamada $\mathrm{m}$ sayıda alternatif ve $\mathrm{n}$ sayıda değerlendirme kriterinden oluşan karar matrisi yukarıdaki eşitlik yardımıyla normalize edilir.

Adım 2: Alternatiflerin Tercih Değerlerinin Hesaplanması. Her bir alternatifin toplam tercih değerleri aşağıdaki eşitlik (8) yardımıyla hesaplanır (Yoon ve Hwang, 1995: 33).

$$
V_{i}=\sum_{j=1}^{n} w_{j} r_{i j} \quad i=1, \ldots \ldots, m
$$

\section{OTOMOTIV FIRMALARININ PERFORMANS DEĞERLEMESINDE ENTROPI, MAUT VE SAW YÖNTEMLERININ UYGULANMASI}

Çalışmanın bu bölümünde BİST'de işlem gören ve Türk otomotiv sektöründe faaliyette bulunan en önemli otomotiv firmalarının performansları MAUT ve SAW yöntemleri ile değerlendirilecektir. Otomotiv firmalarının performansları sermaye, hisse senedi (tl/adet), piyasa değeri (tl), satış geliri (tl), personel sayısı, net kar marjı (\%), cari oran, net kar/sermaye, net kar/satıslar ve net satışlar/personel olmak üzere 10 kriter çerçevesinde değerlendirilecektir. Bu kriterler otomotiv sektöründe performans değerlemesi ile ilgili yapılmış olan çalışmalar (Yıldız, 2006: 1-12 ve Yurdakul ve İç 2003: 1-18) ve uzman görüşlerinden yararlanılarak belirlenmiştir. Alternatif firmaların kriter değerleri bu firmaların 2014 faaliyet raporlarından alınmıştır. Otomotiv firmalarının performanslarının değerlendirilmesinde kullanılacak olan kriterlerin ağırlıkları Entropi yöntemi ile hesaplandıktan sonra MAUT ve SAW yöntemleri birlikte kullanılarak sonuçları karşılaştırılacaktır. Entropi yöntemi, karar vericilerin subjektif yargılarına dayalı olarak kriter ağırlıklarını hesaplamasından dolayı AHP ve Delphi gibi yöntemlere 
göre, eldeki veriyi kullanarak hesaplama yapan objektif ağırlıklandırma yöntemidir (Çakır ve Perçin, 2013: 79). Bu sebeple kriter ağırlıkları için entropi yöntemi tercih edilmiştir. Performans değerlendirme için MAUT ve SAW yöntemleri hesaplama kolaylığı, basit ve anlaşı1ır olması, diğer yöntemlere göre daha az matematiksel işlem gerektirmesi açısından dolayı kullanılmıştır. Ayrıca firmalar için haksız rekabete yol açmamak adına firma isimleri A, B, C, D, E ve F olarak adlandırılmıştır.

BİST’te işlem gören otomotiv sektöründeki firmaların seçilmesi, bu firmaların birbirleriyle karşılaştırılması, sadece firmalar karşılaştırılacağı için yıllık verilerin kullanılması ve firmaların performans değerlemesinde Entropi, SAW ve MAUT gibi çok kriterli karar verme yöntemlerinin kullanılabileceğini göstermek şeklinde çalışmanın kısıtları belirlenmiştir.

\subsection{Entropi Yöntemi İle Kriter Ağırlıklarının Bulunması}

Çalışmada otomotiv firmalarının performanslarının değerlendirilmesinde kullanılacak kriterlerin ağılıklarının hesaplanması için Entropi yöntemi kullanılmıştır. Öncelikle karar matrisinin oluşumu için firmaların faaliyet raporlarından alınan değerler aşağıdaki Tablo 1.'de görülmektedir. Firma isimleri A, B, C, D, E ve F şeklinde kodlanmıştır

Tablo 1. Karar Matrisi

\begin{tabular}{|c|c|c|c|c|c|c|c|c|c|c|}
\hline $\begin{array}{l}\text { Kyiter } \\
\text { Alternat } \\
\text { if }\end{array}$ & $\begin{array}{l}\text { Sermaye } \\
\text { (tl) }\end{array}$ & $\begin{array}{c}\text { Hisse } \\
\text { senedi } \\
\text { (tl) }\end{array}$ & $\begin{array}{l}\text { Piyasa } \\
\text { değeri } \\
\text { (tl) }\end{array}$ & $\begin{array}{c}\text { Satış } \\
\text { geliri (tl) }\end{array}$ & $\begin{array}{c}\text { Personel } \\
\text { sayısı } \\
\text { (kiși) }\end{array}$ & $\begin{array}{c}\text { Net kar } \\
\text { marjı } \\
(\%)\end{array}$ & $\begin{array}{l}\text { Cari } \\
\text { oran } \\
(\%)\end{array}$ & $\begin{array}{c}\text { Net kar/ } \\
\text { Sermaye } \\
(\%)\end{array}$ & $\begin{array}{c}\text { Net kar/ } \\
\text { Sattşlar } \\
\text { (\%) }\end{array}$ & $\begin{array}{c}\text { Net } \\
\text { Satışlar/ } \\
\text { Personel } \\
\text { Sayısı }\end{array}$ \\
\hline $\mathbf{A}$ & $\begin{array}{c}25.420 \\
000\end{array}$ & 22,1 & $\begin{array}{c}593.053 . \\
000\end{array}$ & $\begin{array}{c}729.143 . \\
932\end{array}$ & 869 & 5 & 1,84 & 1,10 & 0,04 & $\begin{array}{c}839.060 \\
91\end{array}$ \\
\hline B & $\begin{array}{c}220.000 \\
000\end{array}$ & 13,9 & $\begin{array}{c}3.069 .00 \\
0.000\end{array}$ & $\begin{array}{c}7.693 .00 \\
0.000\end{array}$ & 2000 & 3,3 & 0,94 & 1,15 & 0,03 & $\begin{array}{c}3.846 .50 \\
0,00 \\
\end{array}$ \\
\hline C & $\begin{array}{c}350.910 \\
000\end{array}$ & 32,3 & $\begin{array}{c}11.404 .6 \\
00.000\end{array}$ & $\begin{array}{c}11.925 .0 \\
00.000\end{array}$ & 9772 & 5 & 1 & 1,70 & 0,05 & $\begin{array}{c}1.220 .32 \\
3,37\end{array}$ \\
\hline D & $\begin{array}{c}460.000 \\
000\end{array}$ & 1,8 & $\begin{array}{c}818.000 \\
000\end{array}$ & $\begin{array}{c}358.284 \\
009\end{array}$ & 1384 & 0,28 & 1,62 & 0,07 & 0,09 & $\begin{array}{c}258.875 \\
73\end{array}$ \\
\hline $\mathbf{E}$ & $\begin{array}{c}24.000 .0 \\
00\end{array}$ & 98,7 & $\begin{array}{c}2.367 .60 \\
0.000\end{array}$ & $\begin{array}{c}994.226 \\
341\end{array}$ & 2054 & 8 & 1,06 & 3,04 & 0,07 & $\begin{array}{c}484.043 \\
98\end{array}$ \\
\hline $\mathbf{F}$ & $\begin{array}{c}500.000 \\
000\end{array}$ & 16,4 & $\begin{array}{c}8.200 .00 \\
0.000\end{array}$ & $\begin{array}{c}7.440 .00 \\
0.000\end{array}$ & 6543 & 6,3 & 1,13 & 1,15 & 0,08 & $\begin{array}{c}1.137 .09 \\
3,08\end{array}$ \\
\hline
\end{tabular}




\section{N. ÖMÜRBEK - M. KARAATLI - H. F. BALCI}

Adım 1: Normalize Edilmiş Standart Karar Matrisi Eşitlik 1 yardımıyla oluşturulur.

Tablo 2. Entropi Yöntemine Göre Normalize Edilmiş Karar Matrisi

\begin{tabular}{|c|c|c|c|c|c|c|c|c|c|c|}
\hline $\begin{array}{c}\text { Kyriter } \\
\text { Altern } \\
\text { atif }\end{array}$ & $\begin{array}{c}\text { Sermay } \\
\text { e }\end{array}$ & $\begin{array}{l}\text { Hisse } \\
\text { Senedi }\end{array}$ & $\begin{array}{l}\text { Piyasa } \\
\text { değeri }\end{array}$ & $\begin{array}{l}\text { Satış } \\
\text { geliri }\end{array}$ & $\begin{array}{c}\text { Personel } \\
\text { sayısı }\end{array}$ & $\begin{array}{c}\text { Net kar } \\
\text { marjı }\end{array}$ & $\begin{array}{l}\text { Cari } \\
\text { oran }\end{array}$ & $\begin{array}{c}\text { Sermaye/ } \\
\text { Net kar }\end{array}$ & $\begin{array}{l}\text { Satışlar/ } \\
\text { Net kar }\end{array}$ & $\begin{array}{c}\text { Net } \\
\text { Satışlar/ } \\
\text { Personel } \\
\text { Sayısı }\end{array}$ \\
\hline $\mathbf{A}$ & $\begin{array}{c}0,01608 \\
5248\end{array}$ & $\begin{array}{c}0,119330 \\
454\end{array}$ & $\begin{array}{c}0,022419 \\
754\end{array}$ & $\begin{array}{c}0,02502 \\
2395\end{array}$ & $\begin{array}{c}0,0384139 \\
33\end{array}$ & $\begin{array}{c}0,17934 \\
0029\end{array}$ & $\begin{array}{c}0,24242 \\
4242\end{array}$ & 0,134154145 & $\begin{array}{c}0,10473 \\
3967\end{array}$ & $\begin{array}{c}0,10776 \\
6761\end{array}$ \\
\hline B & $\begin{array}{c}0,13921 \\
1431\end{array}$ & $\begin{array}{c}0,075053 \\
996\end{array}$ & $\begin{array}{c}0,116020 \\
363\end{array}$ & $\begin{array}{c}0,26400 \\
4505\end{array}$ & $\begin{array}{c}0,0884095 \\
13\end{array}$ & $\begin{array}{c}0,11836 \\
4419\end{array}$ & $\begin{array}{c}0,12384 \\
7167\end{array}$ & 0,140061719 & $\begin{array}{c}0,08969 \\
4864\end{array}$ & $\begin{array}{c}0,49403 \\
4273\end{array}$ \\
\hline C & $\begin{array}{c}0,22204 \\
8559\end{array}$ & $\begin{array}{c}0,174406 \\
048\end{array}$ & $\begin{array}{c}0,431139 \\
079\end{array}$ & $\begin{array}{c}0,40923 \\
6152\end{array}$ & $\begin{array}{c}0,4319688 \\
8\end{array}$ & $\begin{array}{c}0,17934 \\
0029\end{array}$ & $\begin{array}{c}0,13175 \\
2306\end{array}$ & 0,20651083 & $\begin{array}{c}0,13608 \\
2214\end{array}$ & $\begin{array}{c}0,15673 \\
5102\end{array}$ \\
\hline D & $\begin{array}{c}0,29107 \\
8446\end{array}$ & $\begin{array}{c}0,009719 \\
222\end{array}$ & $\begin{array}{c}0,030923 \\
642\end{array}$ & $\begin{array}{c}0,01229 \\
541\end{array}$ & $\begin{array}{c}0,0611793 \\
83\end{array}$ & $\begin{array}{c}0,01004 \\
3042\end{array}$ & $\begin{array}{c}0,21343 \\
8735\end{array}$ & 0,009002076 & $\begin{array}{c}0,25881 \\
7883\end{array}$ & $\begin{array}{c}0,03324 \\
9313\end{array}$ \\
\hline $\mathbf{E}$ & $\begin{array}{c}0,01518 \\
6702\end{array}$ & $\begin{array}{c}0,532937 \\
365\end{array}$ & $\begin{array}{c}0,089504 \\
663\end{array}$ & $\begin{array}{c}0,03411 \\
936\end{array}$ & $\begin{array}{c}0,0907965 \\
7\end{array}$ & $\begin{array}{c}0,28694 \\
4046\end{array}$ & $\begin{array}{c}0,13965 \\
7444\end{array}$ & 0,370453097 & $\begin{array}{c}0,20025 \\
3624\end{array}$ & $\begin{array}{c}0,06216 \\
9327\end{array}$ \\
\hline $\mathbf{F}$ & $\begin{array}{c}0,31638 \\
9615\end{array}$ & $\begin{array}{c}0,088552 \\
916\end{array}$ & $\begin{array}{c}0,309992 \\
499\end{array}$ & $\begin{array}{c}0,25532 \\
2178\end{array}$ & $\begin{array}{c}0,2892317 \\
21\end{array}$ & $\begin{array}{c}0,22596 \\
8436\end{array}$ & $\begin{array}{c}0,14888 \\
0105\end{array}$ & 0,139818133 & $\begin{array}{c}0,21041 \\
7447\end{array}$ & $\begin{array}{c}0,14604 \\
5223\end{array}$ \\
\hline
\end{tabular}

Adım 2: Her bir değer için Entropi değeri Eşitlik 2 yardımıyla oluşturulur. Normalize edilmiş değerler ile bu değerlerin logaritmik değerleri çarpılarak toplanır. Bu toplam en son ' $\mathrm{k}$ ' entropi katsayısı ile çarpılarak tabloya yerleştirilir. Burada entropi katsayısı ' $k$ ' ele alınan firma adedinin logaritmik halidir.

Tablo 3. Entropi Değerinin Hesaplanması

\begin{tabular}{|c|c|c|c|c|c|c|c|c|c|}
\hline Sermaye & $\begin{array}{c}\text { Hisse } \\
\text { Senedi }\end{array}$ & $\begin{array}{c}\text { Piyasa } \\
\text { Değeri }\end{array}$ & $\begin{array}{c}\text { Satış } \\
\text { Geliri }\end{array}$ & $\begin{array}{c}\text { Personel } \\
\text { Sayısı }\end{array}$ & $\begin{array}{c}\text { Net kar } \\
\text { marjı }\end{array}$ & $\begin{array}{c}\text { Cari } \\
\text { oran } \\
\text { Sermaye/Net } \\
\text { kar }\end{array}$ & $\begin{array}{c}\text { Satıșlar/ } \\
\text { Net kar }\end{array}$ & $\begin{array}{c}\text { Net } \\
\text { Satışlar/ } \\
\text { Personel } \\
\text { Sayısı }\end{array}$ \\
\hline $\begin{array}{c}0,815956 \\
768\end{array}$ & $\begin{array}{c}0,752176 \\
423\end{array}$ & $\begin{array}{c}0,7726261 \\
2\end{array}$ & $\begin{array}{c}0,740849 \\
596\end{array}$ & $\begin{array}{c}0,80916312 \\
6\end{array}$ & $\begin{array}{c}0,898286 \\
487\end{array}$ & $\begin{array}{c}0,980807 \\
341\end{array}$ & 0,868366151 & $\begin{array}{c}0,962100 \\
572\end{array}$ & $\begin{array}{c}0,80688 \\
821\end{array}$ \\
\hline
\end{tabular}

Adım 3: Her bir kriterin ağırlık değeri Eşitlik 3 yardımıyla oluşturulur. Ağırlık değerlerinin hesaplanması için hesaplanan entropi değerlerinin her biri 1 den çıkarılarak toplanır. Daha sonra hangi kriter isteniyorsa o değerin entropi değeri 1 den çıkarılarak ilk hesaplanan toplama bölünerek ağırlık değeri bulunur. 
Tablo 4. A ğırlık Değerlerinin Hesaplanması

\begin{tabular}{|c|c|c|c|c|c|c|c|c|c|c|}
\hline $\begin{array}{c}\text { Sermay } \\
\text { e }\end{array}$ & $\begin{array}{c}\text { Hisse } \\
\text { Senedi }\end{array}$ & $\begin{array}{c}\text { Piyasa } \\
\text { Değeri }\end{array}$ & $\begin{array}{c}\text { Staış } \\
\text { Geliri }\end{array}$ & $\begin{array}{c}\text { Personel } \\
\text { Sayısı }\end{array}$ & $\begin{array}{c}\text { Net kar } \\
\text { marjı }\end{array}$ & $\begin{array}{c}\text { Cari } \\
\text { oran }\end{array}$ & $\begin{array}{c}\text { Sermaye/ } \\
\text { Net kar }\end{array}$ & $\begin{array}{c}\text { Satışlar/ } \\
\text { Net kar }\end{array}$ & $\begin{array}{c}\text { Net } \\
\text { Satısslar/ } \\
\text { Personel } \\
\text { Sayısı }\end{array}$ & $\begin{array}{c}\text { TOPL } \\
\text { AM }\end{array}$ \\
\hline $\begin{array}{c}0,11554 \\
849\end{array}$ & $\begin{array}{c}0,155591 \\
922\end{array}$ & $\begin{array}{c}0,142752 \\
918\end{array}$ & $\begin{array}{c}0,16270 \\
3282\end{array}$ & $\begin{array}{c}0,1198137 \\
66\end{array}$ & $\begin{array}{c}0,06385 \\
9142\end{array}$ & $\begin{array}{c}0,01204 \\
9793\end{array}$ & 0,082644128 & $\begin{array}{c}0,02379 \\
4527\end{array}$ & 0,12124 & 2033 \\
\hline
\end{tabular}

Entropi yönteminden elde edilen ağırlıklar 0 ve 1 aralığında olmalı ve elde edilen ağırlıkların toplamı 1 değerini vermelidir. Entropi yöntemi sonuçlarına göre; en önemli kriterin satış geliri olduğu en önemsiz ise cari oran kriterinin olduğu görülmektedir. Bu ağırlıklar MAUT ve SAW yönteminde kullanılacaktır.

\subsection{MAUT Yönteminin Uygulanması}

Otomotiv firmalarının performanslarının değerlendirilmesinde kullanılan kriter ağırlıkları Entropi yönteminden elde edildikten sonra MAUT yönteminde kullanılmıştır.

Adim 1: Nitelik ve Kriterlerin Belirlenmesi: Nitelik ve kriterlerin belirlenmesinde her bir firmanın faaliyet raporlarından alınan değerler aşağıdaki Tablo 5'de görülmektedir.

Tablo 5. Nitelik ve Kriter Değerleri

\begin{tabular}{|c|c|c|c|c|c|c|c|c|c|c|}
\hline $\begin{array}{l}\text { Kyiter } \\
\text { Alterpat } \\
\text { if }\end{array}$ & $\begin{array}{c}\text { Sermaye } \\
\text { (tl) }\end{array}$ & $\begin{array}{c}\text { Hisse } \\
\text { senedi } \\
\text { (tl) }\end{array}$ & $\begin{array}{c}\text { Piyasa } \\
\text { değeri } \\
\text { (tl) }\end{array}$ & $\begin{array}{c}\text { Satıss } \\
\text { geliri(tl) }\end{array}$ & $\begin{array}{c}\text { Personel } \\
\text { sayısı } \\
\text { (kişi) }\end{array}$ & $\begin{array}{c}\text { Net kar } \\
\text { marjı } \\
(\%)\end{array}$ & $\begin{array}{l}\text { Cari } \\
\text { oran } \\
(\%)\end{array}$ & $\begin{array}{c}\text { Net kar/ } \\
\text { Sermaye } \\
(\%)\end{array}$ & $\begin{array}{c}\text { Net } \\
\text { kar/Satış } \\
\text { lar }(\%)\end{array}$ & $\begin{array}{c}\text { Net } \\
\text { Satışlar/ } \\
\text { Personel } \\
\text { Sayısı }\end{array}$ \\
\hline A & $\begin{array}{c}25.420 .0 \\
00\end{array}$ & 22,1 & $\begin{array}{c}593.053 \\
000\end{array}$ & $\begin{array}{c}729.143 . \\
932\end{array}$ & 869 & 5 & 1,84 & 1,10 & 0,04 & $\begin{array}{c}839.060 \\
91 \\
\end{array}$ \\
\hline B & $\begin{array}{c}220.000 \\
000\end{array}$ & 13,9 & $\begin{array}{c}3.069 .00 \\
0.000\end{array}$ & $\begin{array}{c}7.693 .00 \\
0.000\end{array}$ & 2000 & 3,3 & 0,94 & 1,15 & 0,03 & $\begin{array}{c}3.846 .50 \\
0,00\end{array}$ \\
\hline C & $\begin{array}{c}350.910 \\
000\end{array}$ & 32,3 & $\begin{array}{c}11.404 .6 \\
00.000\end{array}$ & $\begin{array}{c}11.925 .0 \\
00.000\end{array}$ & 9772 & 5 & 1 & 1,70 & 0,05 & $\begin{array}{c}1.220 .32 \\
3,37 \\
\end{array}$ \\
\hline D & $\begin{array}{c}460.000 \\
000\end{array}$ & 1,8 & $\begin{array}{c}818.000 \\
000\end{array}$ & $\begin{array}{c}358.284 \\
009\end{array}$ & 1384 & 0,28 & 1,62 & 0,07 & 0,09 & $\begin{array}{c}258.875, \\
73\end{array}$ \\
\hline $\mathbf{E}$ & $\begin{array}{c}24.000 .0 \\
00\end{array}$ & 98,7 & $\begin{array}{c}2.367 .60 \\
0.000\end{array}$ & $\begin{array}{c}994.226 . \\
341\end{array}$ & 2054 & 8 & 1,06 & 3,04 & 0,07 & $\begin{array}{c}484.043, \\
98 \\
\end{array}$ \\
\hline $\mathbf{F}$ & $\begin{array}{c}500.000 \\
000\end{array}$ & 16,4 & $\begin{array}{c}8.200 .00 \\
0.000\end{array}$ & $\begin{array}{c}7.440 .00 \\
0.000\end{array}$ & 6543 & 6,3 & 1,13 & 1,15 & 0,08 & $\begin{array}{c}1.137 .09 \\
3,08 \\
\end{array}$ \\
\hline
\end{tabular}




\section{N. ÖMÜRBEK - M. KARAATLI - H. F. BALCI}

Adım 2: Entropi yöntemi ile bulunan ağırlık değerlerinin toplamının 1'e eşit olmasi.

Tablo 6. Ağırlık Değerlerinin Toplamı

\begin{tabular}{|c|c|c|c|c|c|c|c|c|c|c|}
\hline $\begin{array}{c}\text { Sermay } \\
\mathbf{e}\end{array}$ & $\begin{array}{c}\text { Hisse } \\
\text { Senedi }\end{array}$ & $\begin{array}{c}\text { Piyasa } \\
\text { Değeri }\end{array}$ & $\begin{array}{c}\text { Staış } \\
\text { Geliri }\end{array}$ & $\begin{array}{c}\text { Personel } \\
\text { Sayısı }\end{array}$ & $\begin{array}{c}\text { Net kar } \\
\text { marjı }\end{array}$ & $\begin{array}{c}\text { Cari } \\
\text { oran }\end{array}$ & $\begin{array}{c}\text { Sermaye/ } \\
\text { Net kar }\end{array}$ & $\begin{array}{c}\text { Satışlar/ } \\
\text { Net kar }\end{array}$ & $\begin{array}{c}\text { Net } \\
\text { Satışlar/ } \\
\text { Personel } \\
\text { Sayıs }\end{array}$ & $\begin{array}{c}\text { TOPL } \\
\text { AM }\end{array}$ \\
\hline $\begin{array}{c}0,11554 \\
849\end{array}$ & $\begin{array}{c}0,155591 \\
922\end{array}$ & $\begin{array}{c}0,142752 \\
918\end{array}$ & $\begin{array}{c}0,16270 \\
3282\end{array}$ & $\begin{array}{c}0,1198137 \\
66\end{array}$ & $\begin{array}{c}0,06385 \\
9142\end{array}$ & $\begin{array}{c}0,01204 \\
9793\end{array}$ & 0,082644128 & $\begin{array}{c}0,02379 \\
4527\end{array}$ & $\begin{array}{c}0,12124 \\
2033\end{array}$ & 1 \\
\hline
\end{tabular}

Adım 3: Her bir sütun için en iyi, en kötü değer atamalarının yapılması için her bir sütundaki en iyi değer kalın italik ve altı çizili , en kötü değer ise italik yazı tipi ile yazılmıştır.

Tablo 7. En İyi Ve En Kötü Değerlerin Belirlenmesi

\begin{tabular}{|c|c|c|c|c|c|c|c|c|c|c|}
\hline $\begin{array}{l}\text { Kytiter } \\
\text { Alteyn } \\
\text { atif }\end{array}$ & Sermaye(tl) & $\begin{array}{c}\text { Hisse } \\
\text { senedi } \\
\text { (tl) }\end{array}$ & $\begin{array}{c}\text { Piyasa } \\
\text { Değeri(tl) }\end{array}$ & $\begin{array}{l}\text { Satış Geliri } \\
\text { (tl) }\end{array}$ & $\begin{array}{c}\text { Person } \\
\text { el } \\
\text { Sayısı } \\
\text { (adet) }\end{array}$ & $\begin{array}{c}\text { Net } \\
\text { Kar } \\
\text { Mar } \\
\text { jı } \\
(\%)\end{array}$ & $\begin{array}{c}\text { Cari } \\
\text { Oran } \\
(\%)\end{array}$ & $\begin{array}{c}\text { Net } \\
\text { kar/ } \\
\text { Serma } \\
\text { ye (\%) }\end{array}$ & $\begin{array}{l}\text { Net } \\
\text { kar/ } \\
\text { satış } \\
\text { lar } \\
(\%)\end{array}$ & $\begin{array}{l}\text { Net Satışlar/ } \\
\text { Per. Say. }\end{array}$ \\
\hline $\mathbf{A}$ & 25.420 .000 & 22,1 & 593.053 .000 & 729.143 .932 & $\underline{869}$ & 5 & $\underline{1,84}$ & 1,10 & 0,04 & $839.060,91$ \\
\hline B & 220.000 .000 & 13,9 & 3.069 .000 .000 & 7.693 .000 .000 & 2000 & 3,3 & 0,94 & 1,15 & 0,03 & $\underline{3.846 .500,00}$ \\
\hline $\mathrm{C}$ & 350.910 .000 & 32,3 & $\frac{11.404 .600 .00}{\underline{0}}$ & $\frac{11.925 .000 .00}{\underline{0}}$ & 9772 & 5 & 1 & 1,70 & 0,05 & $1.220 .323,37$ \\
\hline D & 460.000 .000 & 1,8 & 818.000 .000 & 358.284 .009 & 1384 & 0,28 & 1,62 & 0,07 & $\underline{0,09}$ & $258.875,73$ \\
\hline $\mathbf{E}$ & 24.000 .000 & $\underline{98,7}$ & 2.367 .600 .000 & 994.226 .341 & 2054 & $\underline{8}$ & 1,06 & $\underline{3,04}$ & 0,07 & $484.043,98$ \\
\hline $\mathbf{F}$ & $\underline{500.000 .000}$ & 16,4 & 8.200 .000 .000 & 7.440 .000 .000 & 6543 & 6,3 & 1,13 & 1,15 & 0,08 & $1.137 .093,08$ \\
\hline
\end{tabular}

Adım 4: Atanan değerler karar matrisine yerleştirilerek MAUT yönteminde normalize etme işlemine geçilir. Eşitlik 5 yardımıyla veriler normalize edilir. Normalizasyon işleminde öncelikle 3. adımda elde edilen sonuçlara göre her nitelik için en iyi ve en kötü değerler belirlenerek en iyi değere 1, en kötü değere 0 değeri atanır ve diğer değerlerin hesaplanması için, hangi değer isteniyorsa o değerin o sütundaki en kötü değerden farkı, yine aynı sütundaki en iyi değerin en kötü değerden farkına bölünür. 
Tablo 8. MAUT Yöntemine Göre Normalize Edilmiş Karar Matrisi

\begin{tabular}{|c|c|c|c|c|c|c|c|c|c|c|}
\hline $\begin{array}{l}\text { Kkiter } \\
\text { Altern } \\
\text { atif }\end{array}$ & $\begin{array}{c}\text { Sermay } \\
\text { e }\end{array}$ & $\begin{array}{c}\text { Hisse } \\
\text { Senedi }\end{array}$ & $\begin{array}{l}\text { Piyasa } \\
\text { Değeri }\end{array}$ & $\begin{array}{l}\text { Satış } \\
\text { Geliri }\end{array}$ & $\begin{array}{c}\text { Personel } \\
\text { Sayısı }\end{array}$ & $\begin{array}{c}\text { Net Kar } \\
\text { Marjı }\end{array}$ & $\begin{array}{l}\text { Cari } \\
\text { Oran }\end{array}$ & $\begin{array}{l}\text { Net kar/ } \\
\text { Sermaye }\end{array}$ & $\begin{array}{l}\text { Net kar/ } \\
\text { Satışlar }\end{array}$ & $\begin{array}{c}\text { Net } \\
\text { Satışlar/ } \\
\text { Personel } \\
\text { Sayısı }\end{array}$ \\
\hline $\mathbf{A}$ & $\begin{array}{c}0,00298 \\
3193\end{array}$ & $\begin{array}{c}0,20949 \\
4324\end{array}$ & 0 & $\begin{array}{c}0,03206 \\
2681\end{array}$ & 1 & $\begin{array}{c}0,61139 \\
8964\end{array}$ & 1 & 0,346801347 & $\begin{array}{c}0,16666666 \\
7\end{array}$ & $\begin{array}{c}0,16171 \\
8491\end{array}$ \\
\hline B & $\begin{array}{c}0,41176 \\
4706\end{array}$ & $\begin{array}{c}0,12487 \\
1001\end{array}$ & $\begin{array}{c}0,22900 \\
9503\end{array}$ & $\begin{array}{c}0,63412 \\
2598\end{array}$ & $\begin{array}{c}0,87296 \\
4169\end{array}$ & $\begin{array}{c}0,39119 \\
171\end{array}$ & 0 & 0,363636364 & 0 & 1 \\
\hline C & $\begin{array}{c}0,68678 \\
5714\end{array}$ & $\begin{array}{c}0,31475 \\
7482\end{array}$ & 1 & 1 & 0 & $\begin{array}{c}0,61139 \\
8964\end{array}$ & $\begin{array}{c}0,06666 \\
6667\end{array}$ & 0,548821549 & $\begin{array}{c}0,33333333 \\
3\end{array}$ & $\begin{array}{c}0,26799 \\
006\end{array}$ \\
\hline D & $\begin{array}{c}0,91596 \\
6387\end{array}$ & 0 & $\begin{array}{c}0,02080 \\
6181\end{array}$ & 0 & $\begin{array}{c}0,94215 \\
433\end{array}$ & 0 & $\begin{array}{c}0,75555 \\
5556\end{array}$ & 0 & 1 & 0 \\
\hline $\mathbf{E}$ & 0 & 1 & $\begin{array}{c}0,16413 \\
442\end{array}$ & $\begin{array}{c}0,05498 \\
0371\end{array}$ & $\begin{array}{c}0,86689 \\
8798\end{array}$ & 1 & $\begin{array}{c}0,13333 \\
3333\end{array}$ & 1 & $\begin{array}{c}0,66666666 \\
7\end{array}$ & $\begin{array}{c}0,06276 \\
2496\end{array}$ \\
\hline $\mathbf{F}$ & 1 & $\begin{array}{c}0,15067 \\
0795\end{array}$ & $\begin{array}{c}0,70359 \\
4684\end{array}$ & $\begin{array}{c}0,61224 \\
9492\end{array}$ & $\begin{array}{c}0,36268 \\
6735\end{array}$ & $\begin{array}{c}0,77979 \\
2746\end{array}$ & $\begin{array}{c}0,21111 \\
1111\end{array}$ & 0,363636364 & $\begin{array}{c}0,83333333 \\
3\end{array}$ & $\begin{array}{c}0,24479 \\
0781\end{array}$ \\
\hline
\end{tabular}

Adım 5: Eşitlik 6'da gösterildiği gibi, elde edilmiş her bir normalize değer, entropi yöntemi ile hesaplanan ağırlık değerleri ile çarpılarak MAUT yönteminin fayda matrisini oluşturur.

Tablo 9. MAUT Yöntemine Göre Elde Edilmiş Fayda Matrisi

\begin{tabular}{|c|c|c|c|c|c|c|c|c|c|c|c|}
\hline $\begin{array}{l}\text { Krite } \\
\text { Alter } \\
\text { natif }\end{array}$ & $\begin{array}{c}\text { Sermay } \\
\text { e }\end{array}$ & $\begin{array}{c}\text { Hisse } \\
\text { Senedi }\end{array}$ & $\begin{array}{l}\text { Piyasa } \\
\text { Değeri }\end{array}$ & $\begin{array}{l}\text { Satış } \\
\text { Geliri }\end{array}$ & $\begin{array}{c}\text { Person } \\
\text { el } \\
\text { Sayisı }\end{array}$ & $\begin{array}{c}\text { Net } \\
\text { Kar } \\
\text { Marjı }\end{array}$ & $\begin{array}{l}\text { Cari } \\
\text { Oran }\end{array}$ & $\begin{array}{l}\text { Net kar/ } \\
\text { Sermaye }\end{array}$ & $\begin{array}{l}\text { Net kar/ } \\
\text { Satışlar }\end{array}$ & $\begin{array}{c}\text { Net } \\
\text { Satışlar } \\
\text { /Per. } \\
\text { Say. }\end{array}$ & $\begin{array}{c}\text { TOPL } \\
\text { AM }\end{array}$ \\
\hline $\mathbf{A}$ & $\begin{array}{c}0,00034 \\
4703\end{array}$ & 5625 & 0 & $\begin{array}{c}0,00521 \\
6703\end{array}$ & $\begin{array}{c}0,11981 \\
3766\end{array}$ & $\begin{array}{c}0,03904 \\
3413\end{array}$ & $\begin{array}{c}0,01204 \\
9793\end{array}$ & $\begin{array}{c}0,02866109 \\
5\end{array}$ & $\begin{array}{c}0,0039657 \\
55\end{array}$ & $\begin{array}{c}0,01960 \\
7079\end{array}$ & $\begin{array}{c}0,2612 \\
979\end{array}$ \\
\hline B & $\begin{array}{c}0,04757 \\
879 \\
\end{array}$ & $\begin{array}{c}0,01942 \\
8919 \\
\end{array}$ & $\begin{array}{c}0,03269 \\
1775 \\
\end{array}$ & $\begin{array}{c}0,10317 \\
3828 \\
\end{array}$ & $\begin{array}{c}0,10459 \\
3125 \\
\end{array}$ & $\begin{array}{c}0,02498 \\
1167 \\
\end{array}$ & 0 & 0,0300 & 0 & $\begin{array}{c}0,12124 \\
2033 \\
\end{array}$ & $\begin{array}{c}0,4837 \\
42 \\
\end{array}$ \\
\hline C & $\begin{array}{c}0,07935 \\
7052 \\
\end{array}$ & $\begin{array}{c}0,04897 \\
3722 \\
\end{array}$ & $\begin{array}{c}0,14275 \\
2918\end{array}$ & $\begin{array}{c}0,16270 \\
3282 \\
\end{array}$ & 0 & $\begin{array}{c}0,03904 \\
3413 \\
\end{array}$ & $\begin{array}{c}0,00080 \\
332\end{array}$ & $\begin{array}{c}0,04535687 \\
8 \\
\end{array}$ & $\begin{array}{c}0,0079315 \\
09\end{array}$ & $\begin{array}{c}0,03249 \\
166\end{array}$ & $\begin{array}{c}0,5594 \\
138 \\
\end{array}$ \\
\hline D & $\begin{array}{c}0,10583 \\
8533 \\
\end{array}$ & 0 & $\begin{array}{c}0,00297 \\
0143\end{array}$ & 0 & $\begin{array}{c}0,11288 \\
3058 \\
\end{array}$ & 0 & $\begin{array}{c}0,00910 \\
4288 \\
\end{array}$ & 0 & $\begin{array}{c}0,0237945 \\
27 \\
\end{array}$ & 0 & $\begin{array}{c}0,2545 \\
905 \\
\end{array}$ \\
\hline $\mathbf{E}$ & 0 & $\begin{array}{c}0,15559 \\
1922 \\
\end{array}$ & $\begin{array}{c}0,02343 \\
0667\end{array}$ & $\begin{array}{c}0,00894 \\
5487 \\
\end{array}$ & $\begin{array}{c}0,10386 \\
641\end{array}$ & $\begin{array}{c}0,06385 \\
9142 \\
\end{array}$ & $\begin{array}{c}0,00160 \\
6639 \\
\end{array}$ & $\begin{array}{c}0,08264412 \\
8 \\
\end{array}$ & $\begin{array}{c}0,0158630 \\
18 \\
\end{array}$ & $\begin{array}{c}0,00760 \\
9453\end{array}$ & $\begin{array}{c}0,4634 \\
169 \\
\end{array}$ \\
\hline $\mathbf{F}$ & $\begin{array}{c}0,11554 \\
849\end{array}$ & $\begin{array}{c}0,02344 \\
3159\end{array}$ & $\begin{array}{c}0,10044 \\
0194\end{array}$ & $\begin{array}{c}0,09961 \\
5002\end{array}$ & $\begin{array}{c}0,04345 \\
4864\end{array}$ & $\begin{array}{c}0,04979 \\
6896\end{array}$ & $\begin{array}{c}0,00254 \\
3845\end{array}$ & 0,03005241 & $\begin{array}{c}0,0198287 \\
73\end{array}$ & $\begin{array}{c}0,02967 \\
8932\end{array}$ & $\begin{array}{c}0,5144 \\
026\end{array}$ \\
\hline
\end{tabular}

\subsection{SAW Yönteminin Uygulanması}

SAW yönteminin uygulanması için karar matrisi Tablo 10.'daki gibi oluşturulur. 


\section{N. ÖMÜRBEK - M. KARAATLI - H. F. BALCI}

Tablo 10. SAW Yöntemi İçin Karar Matrisi

\begin{tabular}{|c|c|c|c|c|c|c|c|c|}
\hline & $\begin{array}{c}\text { KRİTER } \\
\text { TÜRLERİ }\end{array}$ & $\mathbf{A}$ & B & C & D & $\mathbf{E}$ & $\mathbf{F}$ & $\begin{array}{l}\text { MAK MÍN } \\
\text { r-Rj }\end{array}$ \\
\hline Sermaye (tl) & MAK & 25.420 .000 & $\begin{array}{c}220.000 .0 \\
00 \\
\end{array}$ & $\begin{array}{c}350.910 .0 \\
00 \\
\end{array}$ & $\begin{array}{c}460.000 \\
000\end{array}$ & $\begin{array}{c}24.000 .00 \\
0 \\
\end{array}$ & $\begin{array}{c}500.000 .0 \\
00 \\
\end{array}$ & 500000000 \\
\hline Hisse Senedi (tl) & MAK & 22,1 & 13,9 & 32,3 & 1,8 & 98,7 & 16,4 & 98,7 \\
\hline $\begin{array}{c}\text { Piyasa Değeri } \\
\text { (tl) }\end{array}$ & MAK & 593.053 .000 & $\begin{array}{l}3.069 .000 \\
.000\end{array}$ & $\begin{array}{c}11.404 .60 \\
0.000\end{array}$ & $\begin{array}{c}818.000 . \\
000\end{array}$ & $\begin{array}{l}2.367 .600 \\
.000\end{array}$ & $\begin{array}{l}8.200 .000 \\
.000\end{array}$ & $\begin{array}{c}11.404 .600 .0 \\
00\end{array}$ \\
\hline Satış Geliri (tl) & MAK & 729.143.932 & $\begin{array}{c}7.693 .000 \\
.000 \\
\end{array}$ & $\begin{array}{c}11.925 .00 \\
0.000 \\
\end{array}$ & $\begin{array}{c}358.284 \\
009\end{array}$ & $\begin{array}{c}994.226 .3 \\
41 \\
\end{array}$ & $\begin{array}{c}7.440 .000 \\
.000\end{array}$ & $\begin{array}{c}11.925 .000 .0 \\
00\end{array}$ \\
\hline $\begin{array}{c}\text { Personel } \\
\text { Sayısı(kişi) }\end{array}$ & MIN & 869 & 2000 & 9772 & 1384 & 2054 & 6.543 & 869 \\
\hline $\begin{array}{c}\text { Net kar marjı } \\
(\%)\end{array}$ & MAK & 5 & 3,3 & 5 & 0,28 & 8 & 6,30 & 8 \\
\hline Cari oran (\%) & MAK & 1,84 & 0,94 & 1 & 1,62 & 1,06 & 1,13 & 1,84 \\
\hline $\begin{array}{c}\text { Net } \\
\text { Kar/Sermaye } \\
(\%) \\
\end{array}$ & MAK & 1,1 & 1,15 & 1,7 & 0,07 & 3,04 & 1,15 & 3,04 \\
\hline $\begin{array}{c}\text { Net kar/Satışlar } \\
(\%)\end{array}$ & MAK & 0,04 & 0,03 & 0,05 & 0,09 & 0,07 & 0,08 & 0,09 \\
\hline $\begin{array}{c}\text { Net Satışlar/ } \\
\text { Per. Sayısı }\end{array}$ & MAK & $839.060,91$ & $\begin{array}{c}3.846 .500 \\
, 00\end{array}$ & $\begin{array}{c}1.220 .323, \\
37\end{array}$ & $\begin{array}{c}258.875 \\
73\end{array}$ & $\begin{array}{c}484.043,9 \\
8\end{array}$ & $\begin{array}{c}1137093, \\
08\end{array}$ & $3.846 .500,00$ \\
\hline
\end{tabular}

Adım 1: Eşitlik 7'de gösterildiği gibi karar matrisinin normalize edilmesi için her bir değer kendi satırındaki en büyük değere bölünmelidir.

Tablo 11. SAW Yöntemine Göre Normalize Edilmiş Karar Matrisi

\begin{tabular}{|c|c|c|c|c|c|c|}
\cline { 2 - 7 } \multicolumn{1}{c|}{} & $\mathrm{A}$ & $\mathrm{B}$ & $\mathrm{C}$ & $\mathrm{D}$ & $\mathrm{E}$ & $\mathrm{F}$ \\
\hline Sermaye & 0,05084 & 0,44 & 0,70182 & 0,92 & 0,048 & 1 \\
\hline Hisse Senedi & 0,223910841 & 0,1408308 & 0,327254306 & 0,018237082 & 1 & 0,166160081 \\
\hline Piyasa Değeri & 0,05200121 & 0,269101941 & 1 & 0,071725444 & 0,207600442 & 0,71900812 \\
\hline Satış Geliri & 0,030044781 & 0,030044781 & 0,030044781 & 0,030044781 & 0,083373278 & 0,623899371 \\
\hline Personel SayıSı & 1 & 0,4345 & 0,088927548 & 0,627890173 & 0,423076923 & 0,132813694 \\
\hline Net kar marjı & 0,625 & 0,4125 & 0,625 & 0,035 & 1 & 0,7875 \\
\hline Cari oran & 1 & 0,510869565 & 0,543478261 & 0,880434783 & 0,576086957 & 0,614130435 \\
\hline Net Kar/Sermaye & 0,361842105 & 0,378289474 & 0,559210526 & 0,023026316 & 1 & 0,378289474 \\
\hline Net kar/Satışlar & 0,4444444444 & 0,3333333333 & 0,5555555556 & 1 & 0,777777778 & 0,8888888889 \\
\hline Net Satıșlar/Per. Sayısı & 0,218136204 & 1 & 0,317255523 & 0,067301633 & 0,125840109 & 0,295617595 \\
\hline
\end{tabular}

Adım 2: Normalize edilmiş değerler, Eşitlik 8'de gösterildiği gibi, Entropi yöntemine göre hesaplanmış ağırlık değerleri ile çarpılarak SAW yönteminin fayda matrisini oluşturacaktır. Oluşan değerler sütun olarak toplanır ve en yüksek değer en iyi sonucu verir. 
Tablo 12. SAW Yöntemi İle Hesaplanmış Fayda Matrisi

\begin{tabular}{|c|c|c|c|c|c|c|}
\hline KRITERLER & $\mathrm{A}$ & $\mathrm{B}$ & $\mathrm{C}$ & $\mathrm{D}$ & $\mathrm{E}$ & $\mathrm{F}$ \\
\hline Sermaye & 0,005874485 & 0,050841336 & 0,081094241 & 0,106304611 & 0,005546328 & 0,11554849 \\
\hline Hisse Senedi & 0,034838718 & 0,021912135 & 0,050918126 & 0,002837543 & 0,155591922 & 0,025853166 \\
\hline Piyasa Değeri & 0,007423324 & 0,038415087 & 0,142752918 & 0,010239016 & 0,029635569 & 0,102640507 \\
\hline Satıs Geliri & 0,004888384 & 0,004888384 & 0,0048888384 & 0,004888384 & 0,013565106 & 0,101510475 \\
\hline Personel Sayısı & 0,119813766 & 0,052059081 & 0,010654744 & 0,0752298886 & 0,050690439 & 0,015912909 \\
\hline Net Kar Marjı & 0,039911964 & 0,026341896 & 0,039911964 & 0,00223507 & 0,063859142 & 0,050289074 \\
\hline Cari oran & 0,012049793 & 0,006155873 & 0,006548801 & 0,010609057 & 0,006941729 & 0,007400145 \\
\hline Net Kar/Sermaye & 0,029904125 & 0,031263404 & 0,046215466 & 0,00190299 & 0,082644128 & 0,031263404 \\
\hline Net kar/Satışlar & 0,010575345 & 0,007931509 & 0,013219182 & 0,023794527 & 0,018506854 & 0,021150691 \\
\hline Net Satışlar/Per. Sayısı & 0,026447277 & 0,121242033 & 0,0384644705 & 0,008159787 & 0,015257111 & 0,035841278 \\
\hline SJ & 0,291727182 & 0,361050738 & 0,4346688531 & 0,246200871 & 0,442238327 & 0,507410139 \\
\hline
\end{tabular}

\subsection{MAUT ve SAW Yöntemlerinin Sonuçlarının Karşılaştırılması}

MAUT ve SAW yöntemlerinden elde edilen sonuçlar Tablo 13'de görülmektedir.

Tablo 13. MAUT ve SAW Yöntemlerine Göre Siralamalar

\begin{tabular}{|c|c|c|}
\hline \multicolumn{3}{|c|}{ MAUT Yöntemi } \\
\hline Firmalar & Sonuçlar & Sıralamalar \\
\hline C & 0,5594138 & 1 \\
\hline F & 0,5144026 & 2 \\
\hline B & 0,483742 & 3 \\
\hline E & 0,4634169 & 4 \\
\hline A & 0,2612979 & 5 \\
\hline D & 0,2545905 & 6 \\
\hline
\end{tabular}

\begin{tabular}{|c|c|c|}
\hline \multicolumn{3}{|c|}{ SAW Yöntemi } \\
\hline Firmalar & Sonuçlar & Suralamalar \\
\hline F & 0,507410139 & 1 \\
\hline E & 0,442238327 & 2 \\
\hline C & 0,434668531 & 3 \\
\hline B & 0,361050738 & 4 \\
\hline A & 0,291727182 & 5 \\
\hline D & 0,246200871 & 6 \\
\hline
\end{tabular}

Her iki yönteme göre de ilk iki sırayı $\mathrm{C}$ ve $\mathrm{F}$ firmaları almaktadır. Bu firmalar gerek satış gelirleri, gerekse istihdam ettiği personel sayısı bakımından da performansı yüksek görünen firmalardır.

\section{SONUÇLAR VE ÖNERILLER}

Dünya'da otomotiv sektörü, her yeni gün büyüyen ve ülke ekonomileri için önemi artan bir sektördür. Bu sektörde firmalar arası rekabet hızlı bir şekilde artmakta ve buna bağlı olarak satış gelirleri, kar marjları ve piyasa değeri gibi unsurlar büyük önem kazanmaktadır. Otomotiv sektörü bugün olduğu gibi gelecekte de Türk ekonomisinin en önemli sanayi kollarından biri olma özelliğini koruyacaktır. Vergi gelirlerine, istihdama ve ödemeler dengesine çok büyük 


\section{N. ÖMÜRBEK - M. KARAATLI - H. F. BALCI}

katkılar yapan bu sektörün daha da büyüyüp uluslararası rekabet durumuna gelebilmesi, Türkiye ekonomisinin büyümesi açısından hayati önem taşımaktadır.

Bu çalışmada da ülkemizde 2014 yılında faaliyet gösteren ve BİST'de işlem gören otomotiv sektöründe faaliyette bulunan 6 otomotiv firmasının performanslanı çok kriterli karar verme yöntemleri ile değerlendirilerek en iyi firmanın belirlenmesine çalışılmıştır. Öncelikle firmaların karşılaştırılmasında kullanılacak olan kriterleri belirlemek için bu alanda yapılan çalışmalar ve uzman görüşleri alınarak firmaların 2014 yılı faaliyet raporlarından yararlanılmıştır. Çok kriterli karar verme yöntemlerinde kriterlerin doğru tespit edilmesi çalışmanın kalitesini önemli ölçüde etkilemektedir. Kriter ağırlıkları için Entropi yöntemi kullanılmıştır. Kriter ağırlıklarına bakıldığında önemi en fazla olan kriterler; satış gelirleri $(0,1627)$, hisse senedi değeri $(0,15556)$ ve piyasa değeri $(0,1428)$ krtiterleridir. $\mathrm{Bu}$ bağlamda sıralamada alt sıralarda yer alan firmaların satış geliri, hisse senedi değeri ve piyasa değeri kriterlerinin değerlerinin diğer firmalara göre daha düşük düzeyde olması, sıralamada alt sıralarda yer almalarında etkili olmuştur. Daha sonra MAUT ve SAW yöntemleri ile performans değerlendirme yapılmıştır. MAUT yönteminin sonuçlarına göre 1. firma $C$, 2. firma $F$, SAW yöntemine göre ise 1. firma $F$, 2. firma $E$ firması seçilmiştir. Her iki yönteme göre de başarısız olan firmalar 5. Sirada A ve 6. Sırada D firmalarıdır. Üst sıralarda yer alan firmalar 2015 yılının ilk çeyreğinde otomotiv pazarında yaşanan hareketlenmeyle birlikte iç pazarda ve ihracattaki performanslarını artırarak değer yaratmayı sürdürmüşlerdir. Önümüzdeki yıllarda da daha çok büyümeyi hedeflemektedirler.

Çalışmada temel amaç her bir firmanın yıllara göre kendi içsel performansını değerlendirmek olsaydı son üç yıldaki verileri alınabilirdi. Ancak çalışmadaki temel amaç firmaları birbirleri ile karşılaştırmak ve çok kriterli karar verme tekniklerinin performans değerlemesinde kullanılabildiğini göstermek olduğundan tek bir yıl bazındaki verilerin alınarak yöntemlerin performans değerlendirilmesinde kullanılabildiği gösterilmiştir. Ayrıca gelecekteki çalışmalarda bulanık ortamda karar verme çalışmaları ve diğer çok kriterli karar 
verme yöntemleri ile sektörlere göre farklı kriterler kullanılarak firmaların performans değerlemesinde kullanılabilir.

\section{KAYNAKÇA}

ABDULLAH, L., ADAWIYAH RABIATUL, C. W. (2014), "Simple Additive Weighting Methods of Multi Criteria Decision Making and Applications: A Decade Review", International Journal of Information Processing and Management (IJIPM), 5(1), 34-49.

AFSHARI, A., MOJAHED, M., YUSUFF, R. M. (2010), "Simple Additive Weighting Approach to Personnel Selection Problem", International Journal of Innovation, Management and Technology, 1(5), 511-511.

AHMED A., LAM S. S. (2014), "Material Handling Equipment Selection Using Multi-Attribute Utility Theory and Monte Carlo Simulation", Proceedings of the 2014 Industrial and Systems Engineering Research Conference.

AKTAŞ, R., DOĞANAY, M. M., GÖKMEN, Y., GAZİBEY, Y., TÜREN, U. (2015), "Sayısal Karar Verme Yöntemleri”, Beta Basım A.Ş., İstanbul.

ALP, İ., ÖZTEL A., KÖSE M. S. (2015), "Entropi Tabanlı Maut Yöntemi İle Kurumsal Sürdürülebilirlik Performansı Ölçümü: Bir Vaka Çalışması”, Ekonomik ve Sosyal Araştırmalar Dergisi, 11(2), 65-81.

ANANDA, J., HERATH, G. (2005), "Evaluating Public Risk Preferences in Forest Land-Use Choices Using Multi-Attribute Utility Theory", Ecological Economics, $55,408-419$.

ANTIL, P., SINGH, M. (2013), "Performance Measurement of An Industry Using Simple Additive Weight", International Journal for Research in Applied Sclence and Engineering Technology, 1(3), 1-3.

ASHOUR, O., OKUDAN KREMER, G. E. (2013), “A Simulation Analysis of The Impact of FAHP-MAUT Triage Algorithm On the Emergency Department Performance Measures", Expert Systems with Applications, 40, 177-187.

AYTAÇ, M., GÜRSAKAL, N. (2015), Karar Verme, Dora Basım Yayın Dağıtım A.Ş., Bursa.

BALLI S., KARASULU B., KORUKOĞLU S. (2007), "En Uygun Otomobil Seçimi Problemi İçin Bir Bulanık Promethee Yöntemi Uygulaması", Dokuz Eylül Üniversitesi İktisadi ve İdari Bilimler Fakültesi Dergisi, 22(11), 39-147. 


\section{N. ÖMÜRBEK - M. KARAATLI - H. F. BALCI}

BOSTANCI, S. H., OCAKÇI, M., ŞEKERCİ, S. (2006), "Kentsel Silüetin Çeşitlilik Açısından Değerlendirilmesinde Entropi Yaklaşımı", Journal of İstanbul Kültür University, 2, 83-95.

CANBOLAT, Y. B., CHELST, K., GARG, N. (2007), "Combining Decision Tree and MAUT for Selecting A Country for A Global Manufacturing Facility", Omega, $35,312-325$.

CHEN W., FENG D., CHU X. (2015), "Study of Poverty Alleviation Effects for Chinese Fourteen Contiguous Destitute Areas Based on Entropy Method", International Journal of Economics and Finance, 7(4:2), 89-98.

CHEN, T., JIN, Y., QIU, X., CHEN, X. (2014), “A Hybrid Fuzzy Evaluation Method for Safety Assessment of Food-Waste Feed Based on Entropy and The Analytic Hierarchy Process Methods", Expert Systems with Applications, 41, $7328-7337$.

CHON-HUAT, G., YUNG-CHIN, A. T., CHUN-HUNG, C. (1995), "A Revised Weighted Sum Decision Model For Robot Selection", Computers Industry Engineering, 30(2), 193-199.

ÇAKIR, S., PERÇiN, S. (2013), "Çok Kriterli Karar Verme Teknikleriyle Lojistik Firmalarında Performans Ölçüm”, Ege Akademik Bakış Dergisi, 13(4), 449-459.

ÇAKIR, S., PERÇİN, S. (2013), “AB Ülkeleri’nde Bütünleşik Entropi AğırlıkTopsıs Yöntemiyle Ar-Ge Performansının Ölçülmesi”, Uluda ğ Üniversitesi İktisadi ve İdari Bilimler Fakültesi Dergisi, 32(1), 77-95.

ÇETIN, M. (2000), “Avrupa Birliği Sürecinde Küçük ve Orta Büyüklükte İssletmeler ve Rekabet Gücü (Otomotiv Yan Sanayi Örneği)", Dokuz Eylül Üniversitesi İktisadi ve İdari Bilimler Fakültesi Dergisi, 15(2), 69-84.

ÇINAR, Y. (2004), Çok Nitelikli Karar Verme ve Bankaların Mali Performanslarının Değerlendirilmesi Örneği, Ankara Üniversitesi Sosyal Bilimler Enstitüsü İşletme Anabilim Dalı, Yüksek Lisans Tezi, Ankara.

ESKANDARI M., HOMAEE M., MAHMOODI S., PAZIRA E., VAN GENUCHTEN M. T. H. (2015), "Optimizing Landfill Site Selection by Using Land Classification Maps", Environmental Science and Pollution Research, 22, 7754-7765.

GOH, C. H., TUNG, Y. C. A., CHENG, C. H. (1995), "A Revised Weighted Sum Decision Model For Robot Selection", Computers Industry Engineering, 30(2), 193-199. 
GOMEZ LIMON, J. A., ARRIAZA, M., RIESGO, L. (2003), “An MCDM Analysis of Agricultural Risk Aversion", European Journal of Operational Research, 151, 569-585.

GÖRENER, A., GÖRENER, Ö. (2008), “Türk Otomotiv Sektörünün Ülke Ekonomisine Katkıları Ve Geleceğe Yönelik Sektörel Beklentiler”, Journal of Yasar University, 3(10), 1213-1232.

ISHIZAKA, A., NEMERY, P. (2013), Multi-Criteria Decision Analysis:Methods and Software, John Wiley \& Sons Ltd. Published, Chichester/UK.

JABERIDOOST M., OLFAT L., HOSSEINI A., KEBRIAEEZADEH A ABDOLLAHI M., ALAEDDINI M., DINARVAND R. (2015), "Pharmaceutical Supply Chain Risk Assessment in Iran Using Analytic Hierarchy Process (AHP) and Simple Additive Weighting (SAW) Methods", Journal of Pharmaceutical Policy and Practice, 8(1:9), 1-10.

KAILIPONI, P. (2010), "Analyzing Evacuation Decisions Using Multi-Attribute Utility Theory (MAUT)", 1.International Conference on Evacuation Modeling and Management, Procedia Engineering, 3, 163-174.

KAPUR P. K., SINGH J. N. P., SINGH O. (2015), "Application of Multi Attribute Utility Theory in Multiple Releases of Software", The Society for Reliability Engineering, 6(1), 61-70.

KIM, K. S., SONG, O. (2009), "A MAUT Approach For Selecting a Dismantling Scenario for The Thermal Column in KRR-1", Annals of Nuclear Energy, 36, 145150.

KIM, S. K., PARK, H. S., LEE, K. W., JUNG, C. H. (2007), "MAUT Approach for Selecting a Proper Decommissioning Scenario", WM'07 Conference, February 25-March 1, Tucson.

KONUŞKAN, Ö., UYGUN, Ö. (2014), "Çok Nitelikli Karar Verme (MAUT) Yöntemi ve Bir Uygulamas1”, ISITES 2014, 1403-1412.

KÜÇÜKÖNDER, M., KARABULUT, M., (2007), "Çok Kriterli Analiz Yöntemi Kullanılarak Kahramanmaraş’ta Çöp Depolama Alanı Tespiti”, Coğrafi Bilimler Dergisi, 5, 55-76.

LEE, P. T. W., LIN, C. W., SHIN, S. H., (2012), “A Comparative Study on Financial Positions of Shipping Companies in Taiwan and Korea Using Entropy and Grey Relation Analysis", Expert Systems with Applications 39, 5649-5657. 


\section{N. ÖMÜRBEK - M. KARAATLI - H. F. BALCI}

LOETSCHER, T., KELLER, J. (2002), “A Decision Support System for Selecting Sanitation Systems in Developing Countries", Socio-Economic Planning Sciences, 36, 267-290.

LOPES Y. G., ALMEIDA A. T. (2015), "Assessment of Synergies for Selecting A Project Portfolio in The Petroleum Industry Based on A Multi-Attribute Utility Function", Journal of Petroleum Science and Engineering, 126, 131-140.

SALİH Y. K., SEE O. H., IBRAHIM R. W., YUSSOF S., IQBAL A. (2015), “A Novel Noncooperative Game Competing Model Using Generalized Simple Additive Weighting Method to Perform Network Selection in Heterogeneous Wireless Networks", International Journal Of Communication Systems, 28, 11121125 .

SHAKOURI, G. H., NABAEE, M., ALIAKBARISANI, S. (2014), “A Quantitative Discussion on the Assessment of Power Supply Technologies: DEA (Data Envelopment Analysis) and SAW (Simple Additive Weighting) as Complementary Methods for the 'Grammar'”, Energy, 64, 640-647.

ÖZKUL, S. (2001), "Su Kalitesi Gözlem Ağlarının Entropi Yöntemi ile Değerlendirilmesi”, Turk Journal Engineering Environment Science, 25, 435-452.

SAVITHA, K., HANDRASEKAR, C. (2011), "Vertical Handover Decision Schemes Using Saw and Wpm for Network Selection in Heterogeneous Wireless Networks", Global Journal of Computer Science and Technology, 11(9), 18-24.

SHEMSHADI, A., SHIRAZI, H., TOREIHI, M., TAROKH M. J. (2011), “A Fuzzy VIKOR Method for Supplier Selection Based on Entropy Measure for Objective Weighting”, Expert Systems with Applications, 38, 12160-12167.

TÜRKOĞLU, M., UYGUN, Ö. (2014), "VIKOR-MAUT Yöntemleri Kullanılarak Çukurova Bölgesel Havaalanı Yeri Seçimi”, ISITES, 1425-1433.

WANG, S.O., WEE, Y.P., OFORI, G., (2002), "DSSDSS: A Decision Support System for Dewatering Systems Selection", Building and Environment, 37, 625645 .

WANG, T. C., LEE, H. D. (2009), "Developing A Fuzzy TOPSIS Approach Based on Subjective Weights and Objective Weights", Expert Systems with Applications, $36,8980-8985$.

WU, H. Y., TZENG, G. H., CHEN, Y. H. (2009), “A Fuzzy MCDM Approach for Evaluating Banking Performance Based on Balanced Scorecard", Expert Systems with Applications, 36, 10135-10147. 
YEH, C. H. (2003), "The Selection of Multiattribute Decision Making Methods for Scholarship Student Selection", Internatıonal Journal of Selection And Assessment, 11(4), 289-296.

YILDIZ, A. (2006), “Otomotiv Sektörü Performansının Değerlendirmesi”, Muğla Üniversitesi, Sosyal Bilimler Enstitüsü Dergisi, 16, 1-12.

YOON, K. P., HWANG, C. L. (1995), "Multiple Attribute Decision Making An Introuction", Sage University Papers, London.

YURDAKUL, M., İÇ, Y. T. (2003), "Türk Otomotiv Firmalarının Performans Ölçümü ve Analizine Yönelik Topsis Yöntemini Kullanan Bir Örnek Çalışma”, Gazi Üniversitesi Mühendislik Mimarlık Fakültesi Dergisi, 18(1), 1-18.

ZHANG Y., CHEN J., CHEN Z., NIE Z. (2015), "Improving Assessment Of Groundwater Sustainability With Analytic Hierarchy Process and information Entropy Method: A Case Study of The Hohhot Plain, China", Environment Earth Science, 73, 2353-2363.

ZIONTS, S. (1979), "MCDM: If not a Roman Numeral then What?", Interfaces, 9(4), 94-101. 